\title{
Petera L. Bergera przejście od teorii sekularyzacji do teorii desekularyzacji
}

\begin{abstract}
In this paper I present the evolution of views of the american sociologist Peter L. Berger which is a transition from the theory of secularization into the theory of desecularization. He was one of the major representatives of the secualrization paradigm and since the 1990's he became the creator and adherent of the desecularization paradigm. Desecularization means a persistent and strong presence of religion in the modern world or as a social process it is a reverse version of secularization. According to Berger contemporary sociology of religion should take care of research on the forces affecting mutually secularization and desecularization because "antisecularism is a phenomenon just as important in the modern world as secuarlization." Berger until the end of 1970's did focus on the analysis of the secularization processes and later on he commited his research to the issue if desecularization processes.
\end{abstract}

Keywords: religion, Christian Churches, secualization, desecularization

$\mathrm{M}$ odernizacja społeczna związana z urbanizacją i industrializacją, wzrastającym dobrobytem i pluralizacją społeczno-kulturową pociągała za sobą daleko idące zmiany w sferze religijnej i więzi z Kościołami chrześcijańskimi, zwłaszcza w Europie Zachodniej. Autonomizacja polityki doprowadziła do rozdziału Kościoła i państwa, a zorganizowane religie (Kościoły) coraz częściej były eliminowane ze sfery życia publicznego, przesuwały się do dziedziny życia prywatnego. W wyniku procesów modernizacyjnych religie (zwłaszcza w kościelnej formie) ulegały erozji, zarówno w wymiarze indywidualnym, jak i społecznym. 
Peter L. Berger (1929-2017), socjolog amerykański, wymienił kilka przyczyn łączenia sekularyzacji z modernizacją społeczną: a) dominacja myślenia naukowego, które czyniąc świat racjonalnie bardziej zrozumiałym i sterowalnym, pozostawiało mniej przestrzeni dla tego, co nadprzyrodzone; b) postępujące zróżnicowanie nowoczesnych instytucji, między innymi zerwanie połączenia państwa i Kościoła w nowożytnym społeczeństwie demokratycznym, które uczyniły z przynależności wyznaniowej i religijnej kwestię dobrowolną; c) nowoczesne procesy migracji, industrializacji, urbanizacji i rozwoju komunikacji masowej, które podkopały tradycyjne sposoby życia. Modernizacja społeczna i sekularyzacja kształtują się rozmaicie w różnych kontekstach historycznych, politycznych i społeczno-kulturowych $^{1}$.

Peter L. Berger często podkreślał, że Europa Zachodnia i Środkowa to najbardziej zsekularyzowany obszar świata. Najpierw zjawisko „euroświeckości” (eurosekularyzmu) było charakterystyczne dla północnej części kontynentu europejskiego, potem rozszerzało się niezwykle szybko na inne rejony Europy (na przykład Francję, Belgię, Hiszpanię). W tym kontekście Berger stawia hipotezę, że kolejne kraje poddają się sekularyzacji w miarę jak są przyłączane do Europy. Integracja europejska sprzyja przyjmowaniu „euroświeckości” wraz z całym „pakietem europejskim”. Tendencję tę - jego zdaniem - można już zauważyć w przypadku Irlandii i Polski, gdzie mamy do czynienia jedynie z opóźnieniem tego procesu. „Nowa” Europa będzie już wkrótce wyglądać jak „stara”2 Ex definitione wyklucza się ożywienie religijne w skali społecznej.

Według Petera L. Bergera teoria sekularyzacji wywodząca się z Oświecenia i spopularyzowana w latach 50. i 60. ubiegłego wieku (między innymi przy jego istotnym udziale), wskazująca, że modernizacja społeczna z konieczności prowadzi do upadku religii zarówno w społeczeństwie, jak i w świadomości ludzi, okazała się błędna. Sekularyzacja na płaszczyźnie społecznej nie zawsze łączy się z sekularyzacją na płaszczyźnie świadomości indywidualnej. Niektóre instytucje kościelne utraciły siłę i wpływy w wielu społeczeństwach, ale zarówno dawne, jak i nowe przekonania religijne oraz praktyki trwały nadal w życiu jednostek, czasami przybierając nowe formy instytucjonalne, czasami prowadząc nawet do wielkich

${ }^{1}$ P.L. Berger, Refleksje o dzisiejszej socjologii religii, tłum. K. Marulewska, „Teologia Polityczna” 2009/2010, nr 1 s. 90; J. Mariański, „Odkościelnienie” i indywidualizacja jako ważne tendencje przemian religijności współczesnej, „Zeszyty Naukowe. Publikacje z zakresu europejskiej integracji, polityki i bezpieczeństwa. Redakcja Zeszytów Naukowych Akademii Marynarki Wojennej”, Gdynia 2010, ss. 169-194.

${ }_{2}^{2}$ P.L. Berger, Alternatywne nowoczesności, www.newsweek.pl/alternatywne-nowoczesnosci,45397,1,1.html [dostęp: 3.05.2019]; B. Milerski, Religia w społeczeństwie pluralistycznym, w: Elementy pedagogiki religijnej, red. B. Milerski, Chrześcijańska Akademia Teologiczna, Warszawa 1998, ss. 226-231; T. Knauth, Peter Bergers Religionstheorien, ihre Bedeutung für die Entwicklung einer pluralitätsfähigen Religionspädagogik, w: Im Gespräch mit Peter L. Berger. Eine Gedenkschrift zu den Perspektiven und Grenzen religiöser Pluralität, Hrsg. von Wolfram Weiße, Silke Steets, Waxmann Verlag, Münster 2019, ss. 111-119. 
eksplozji gorliwości religijnej. I odwrotnie, instytucje identyfikowane jako religijno-kościelne mogą odgrywać pewną rolę społeczną i polityczną nawet wtedy, jeśli niewielu ludzi wierzy lub praktykuje religię, którą te instytucje reprezentują. Relacja religii i nowoczesności jest dość złożona, a świat dzisiejszy nie jest bynajmniej zsekularyzowany. Sekularyzacja powoduje silne ruchy kontrsekularyzacyjne ${ }^{3}$.

Berger mówi o międzynarodowej subkulturze, złożonej z ludzi posiadających wyższe wykształcenie typu zachodniego, w naukach humanistycznych, a zwłaszcza w socjologii, która jest rzeczywiście zsekularyzowana. Subkultura ta stanowi ważny nośnik „postępowych” i „oświeceniowych” wartości i przekonań. Jej członkowie są w społeczeństwach mniejszością, ale wywierają znaczący wpływ na innych, ponieważ kontrolują instytucje dostarczające „oficjalnych” definicji rzeczywistości poprzez system edukacyjny, prawny i poprzez media masowego komunikowania. Mamy tu do czynienia ze zglobalizowaną kulturą elitarną. Wiarygodność teorii sekularyzacji zawdzięcza wiele tej międzynarodowej subkulturze ${ }^{4}$. Z socjologicznego punktu widzenia ważne jest pytanie, jak ta intelektualna subkultura będzie działać w coraz bardziej globalizującym się świecie.

Europa jest wyjątkowa, a jej laicyzm stanowi jedno z najciekawszych zagadnień współczesnej socjologii religii.

Mówi się często, że nowoczesność powoduje upadek religii, poglądowi temu nadano miano „teoria sekularyzacji”. Dziś większość socjologów religii zgadza się, że doświadczenie wykazało fałszywość tej teorii. Sam byłem jej zwolennikiem i dopiero na początku lat 70. uznałem, że nie da się jej obronić. Teoria owa okazała się bowiem całkowicie niezdolna do wyjaśnienia różnicy między Ameryką a Europą. Trudno argumentować, że Belgia jest krajem bardziej nowoczesnym od USA. Tym większym zaskoczeniem jest więc to, co uchodzi za amerykańską egzotykę - niepojęte upodobanie tamtejszego społeczeństwa do pobożności 5 .

W niniejszym artykule przedstawiam ewolucję poglądów socjologa amerykańskiego Petera L. Bergera, będącą przejściem od teorii sekularyzacji do teorii desekularyzacji ${ }^{6}$. Był on jednym z czołowych przedstawicieli paradygmatu se-

${ }^{3}$ P.L. Berger, The Desecularization of the World: A Global Overview, w: The Desecularization of the World: Resurgent Religion and World Politics, ed. P.L. Berger, Ethics and Policy Center, Washington 1999, ss. 2-3; P.L. Berger, Sekularyzacja a problem wiarygodności religii, w: Socjologia religii, red. F. Adamski, Wydawnictwo Apostolstwa Modlitwy, Kraków 1983, ss. 364-378.

${ }^{4}$ P.L. Berger, The Desecularization of the World..., ss. 1-18.

${ }^{5}$ P.L. Berger, Zachód z Bibliq w tle, „Gazeta Wyborcza” z 2005 r., nr 158, s. 18; J. Mariański, Nowa religijność i duchowość - mit czy rzeczywistość? Studium socjologiczne, Warszawskie Wydawnictwo Socjologiczne, Warszawa 2019.

${ }^{6}$ I. Borowik, Berger Peter Ludwig, w: Leksykon socjologii religii. Zjawiska-badania-teorie, red. M. Libiszowska-Żółtkowska, J. Mariański, Verbinum Wydawnictwo Księży Werbistów, Warszawa 2004, ss. 35-36; Ł. Kutyło, Między sekularyzacjq̨ a desekularyzacją. W poszukiwaniu globalnej teorii przemian religijnych, „Annales Universitatis Paedagogicae Cracoviensis. Studia Sociologica” VI, 2014, nr 1, ss. 14-17; J. Majka, Metodologia nauk teologicznych, Wydawnictwo Wrocławskiej Księgarni Archidiecezjalnej, Wrocław 1981, ss. 364-365. 
kularyzacyjnego, od lat 90. XX wieku stał się twórcą i gorącym zwolennikiem paradygmatu desekularyzacji. Desekularyzacja oznacza utrzymującą się silną obecność religii we współczesnym świecie lub jako proces społeczny odwrotny od sekularyzacji . Według Bergera współczesna socjologia religii powinna zająć się badaniem wzajemnych oddziaływań sił sekularyzacyjnych i antysekularyzacyjnych, bowiem „antysekularyzm jest co najmniej zjawiskiem równie we współczesnym świecie ważnym co sekularyzacja”. Berger do końca lat 70. XX wieku zajmował się przede wszystkim analizą procesów sekularyzacyjnych, w późniejszym okresie sporo miejsca poświęcił analizie procesów desekularyzacyjnych ${ }^{9}$.

Powolne zmiany swojego stanowiska Berger wyjaśniał krótko:

Jeśli chodzi o moje zapatrywania na socjologię współczesnej religii, to sądzę, że główna zmiana w sposobie myślenia, polegająca dokładnie na porzuceniu starej teorii sekularyzacji, dokonała się - jak chciałbym podkreślić - nie z uwagi na jakąś przemianę filozoficzną czy teologiczną, lecz bez względu na to, że była coraz mniej zdolna do wyjaśnienia danych empirycznych dotyczących różnych części świata (zwłaszcza Stanów Zjednoczonych). Jak lubię powtarzać moim studentom, jedną z zalet bycia socjologiem (w przeciwieństwie do bycia powiedzmy filozofem czy teologiem) jest to, że można mieć równie dobrą zabawę wtedy, gdy czyjeś teorie są wyssane z palca, jak i gdy są potwierdzane empirycznie! $!^{10}$

\section{Teoria sekularyzacji w ofensywie}

Z socjologiczne i psychospołecznego punktu widzenia religię można określić jako poznawczą i normatywną strukturę, która powoduje, że człowiek czuje się w uniwersum ,jak u siebie w domu”. W społeczeństwie pluralistycznym różne sektory życia społecznego są kierowane przez sprzeczne znaczenia i systemy znaczeń. Integrowanie pluralizmu ,społecznych światów życia” w jeden zwarty „świat” staje się coraz trudniejsze dla tradycji religijnych i kościelnych instytucji. Co więcej, jest zagrożone od wewnątrz, tj. ze strony subiektywnej świadomości jednostek. Upowszechnia się w społeczeństwach nowoczesnych zjawisko sekularyzacji ${ }^{11}$.

7 T. Doktór, Wokół problemu sekularyzacji, w: P. Norris, R. Inglehart, Sacrum i profanum. Religia i polityka na świecie, tłum. R. Babińska, Zakład Wydawniczy Nomos, Kraków 2006, ss. 8-9; J. Mariański, Religia i religijność w społeczeństwie tradycyjnym i nowoczesnym w ujęciu Petera L. Bergera, „Collectanea Theologica” 2020, vol. 90, nr 2, ss. 230-254.

${ }_{8}$ P.L. Berger, The Desecularization of the World..., s. 69; Z. Drozdowicz, Between the temptations of privatizing and globalizing religion, „Przegląd Religioznawczy” 2014, nr 1, ss. $3-12$.

${ }^{9}$ H. Knoblauch, Silke Steets. Dialektik und Dialog im Dazwischen. Nekrolog auf Peter L. Berger (1929-2017) und Thomas Luckmann (1927-2016), „Berliner Journal für Soziologie” 2018, vol. 27, nr 3-4, ss. 595-601.

${ }^{10}$ P.L. Berger, Refleksje o dzisiejszej socjologii religii, s. 91.

${ }^{11}$ P.L. Berger, B. Berger, H. Kellner, Bezdomny umysł, w: Zjawisko wspólnoty (Wybór tekstów), red. B. Mikołajewska, Instytut Profilaktyki i Resocjalizacji Społecznej UW, Warszawa 
Pojęcie sekularyzacji zawiera różnorodne treści: po pierwsze, jest rozumiane jako zeświecczenie religii, czyli postępujące w Europie Zachodniej osłabienie znaczenia chrześcijaństwa w życiu społecznym, rozpatrywane zarówno z punktu widzenia kryteriów emancypacji, jak i krytyki kulturowej; po drugie, jako usuwanie autorytetów kościelnych z dziedzin świeckiego panowania i władzy, co jest związane z utratą kontroli sprawowanej przez religię nad życiem społecznym; po trzecie, jako usuwanie i zachowywanie zarazem „dzieł” (dorobku) chrześcijaństwa w życiu świeckim, na przykład obecność elementów tradycji chrześcijańskiej we współczesnej kulturze, coś w rodzaju „chrześcijaństwa poza Kościołem”; po czwarte, jako warunek demitologizacji wiary i zarazem „uduchowienia sfery świeckiej”; po piąte, jako dechrystianizacja i „odkościelnienie” szerokich kręgów społeczeństw współczesnych ${ }^{12}$.

Sekularyzacja jako proces społeczno-kulturowy dokonuje się zarówno na płaszczyźnie instytucji i organizacji społecznych, jak i na płaszczyźnie ludzkiej świadomości. Jest swoistą „sygnaturą” czasów współczesnych, skutkiem dokonujących się procesów dyferencjacji społecznej, pluralizacji społeczno-kulturowej, dezinstytucjonalizacji i racjonalizacji. Wieloznaczność terminu „sekularyzacja”, ale i terminu „religia” (niejasność i nieokreśloność), utrudniają przeprowadzenie precyzyjnych rozważań dotyczących chrześcijaństwa, sekularyzacji i tak zwanej nowoczesności. Sprecyzowanie pojęcia sekularyzacji pozwoliłoby dokładniej ująć swoiste napięcia, jakie sygnalizuje para pojęć „religia - nowoczesność”, często nawet ujmowanych jako pojęcia przeciwstawne.

Klasyczne teorie sekularyzacji wskazywały na modernizację społeczną (industrializacja, urbanizacja, dyferencjacja społeczna, mobilność, nauka i technika, instytucje demokratyczne, racjonalizacja itp.) jako na zasadniczy motor przemian sekularyzacyjnych. Nieuchronną konsekwencją modernizacji - twierdzi się - jest zanikanie religii w sferze życia publicznego, ale także w indywidualnej i zbiorowej świadomości (linearny spadek religijności). Według zwolenników tezy o globalnej sekularyzacji religia traktowana jako siła tradycyjna musi kapitulować w warunkach dyferencjacji społecznej, pluralizacji i indywidualizacji; jedna ze stron wygrywa kosztem drugiej. Rzadko zdarza się, by zwolennicy teorii sekularyzacji określali zanik religii i Kościołów chrześcijańskich w najbliższej przyszłości lub mówili o zgonie religii.

Wśród socjologów było wielu zwolenników poglądu, że sekularyzacja ma charakter liniowy i nieodwracalny. Religia ulega marginalizacji, instytucje religijne są

1989, ss. 498-499; J. Mariański, Sekularyzacja we współczesnym świecie w ujęciu Petera L. Bergera, w: Społeczeństwo - kultura - wychowanie. Księga jubileuszowa dedykowana Profesorowi Januszowi Sztumskiemu z okazji 90-lecia urodzin, red. F. Bylok, M. Łapot, K. Rędziński, Uniwersytet Humanistyczno-Przyrodniczy im. Jana Długosza w Częstochowie, Częstochowa 2020, ss. 81-99.

12 F.-X. Kaufmann, Wie überlebt das Christentum?, Verlag Herder, Freiburg im Breisgau 2000, ss. 84-85. 
eliminowane z życia społecznego, zwłaszcza o charakterze publicznym. Jako swoisty subsystem rozwija ona własne wartości i swoją logikę działania, ale traci nośność społeczną, podlega społecznej relatywizacji. Religia i Kościoły chrześcijańskie tracą stopniowo wpływ na różne segmenty życia społecznego. W wyniku sekularyzacji - pisze Peter L. Berger - „prawdopodobnie po raz pierwszy w historii religijnej legitymizacje świata straciły swoją wiarygodność nie tylko dla kilku intelektualistów i innych nie liczących się jednostek, lecz dla szerokich mas całych społeczeństw”"13.

Większość myślicieli wywodzących się z tradycji oświeceniowych skłaniała się do poglądu, że sekularyzacja to dobra rzecz, przynajmniej w tym sensie, że prowadzi do likwidacji tych zjawisk religijnych, które są określane jako zacofane, zabobonne czy reakcyjne. Sekularyzacja, a nawet sekularyzm, ostatecznie zatriumfuje ${ }^{14}$. Nawet wśród ludzi określających się jako wierzący można obserwować osłabienie wpływu wiary na życie społeczne. Demontaż religijności kościelnej jest opisywany przez socjologów jako fakt społeczny. Według zwolenników teorii sekularyzacji nie ma wyraźnych i jednoznacznych symptomów powrotu religii, są co najwyżej chwilowe wahnięcia trendu, niezmieniające dominujących tendencji.

Teoria sekularyzacji upowszechniła się w socjologii zachodniej w latach 60 . i 70. ubiegłego wieku. Jednym z jej zdecydowanych zwolenników był Peter L. Berger. Na początku lat 70. Peter L. Berger i Brigitte Berger pisali o sekularyzacji jako głównym problemie socjologii religii. Totalny proces sekularyzacji oznacza stałą utratę znaczenia religii we wszystkich dziedzinach życia. Nie tylko instytucje religijne są spychane na margines życia społecznego, ale także religijne wartości i normy tracą swoje znaczenie dla usensowienia ludzkiego życia. Na płaszczyźnie świadomości przykładem ogólnej sekularyzacji jest prywatna moralność. Coraz mniej ludzi poszukuje zasad dla swojego życia osobistego w ustabilizowanych tradycyjnych religiach ${ }^{15}$. Sekularyzacja oddziałuje szczególnie destrukcyjnie na tradycyjne treści i na instytucje, które ją upowszechniały. Rodzi pluralizm i sama jest wspierana przez pluralizm ${ }^{16}$.

W społeczeństwach nowoczesnych i ponowoczesnych granice organizacji społecznych i światopoglądowych nie są ściśle określone. Wyraźne granice światopoglądów ulegają neutralizacji. W wielu dziedzinach życia zaznaczają się procesy dezorganizacji (na przykład w kulturze młodzieżowej, w wychowaniu, w rodzinie) i emocjonalnej destabilizacji jednostek (na przykład rozczarowania, konflikty, dylematy, dramaty psychiczne). Społeczeństwo pluralistyczne stanowi kompleksową i trudną do ogarnięcia strukturę, w której wielu ludzi boryka się ze

${ }^{13}$ P.L. Berger, Święty baldachim. Elementy społecznej teorii religii, tłum. W. Kurdziel, Zakład Wydawniczy Nomos, Kraków 1971, s. 171.

${ }^{14}$ P.L. Berger, Zachód z Bibliq w tle, ss. 18-19.

15 P.L. Berger, Brigitte Berger. Individuum \& Co. Soziologie beginnt beim Nachbarn, Deutsche Verlag-Anstalt, Stuttgart 1974, s. 221.

${ }^{16}$ P.L. Berger, Święty baldachim..., ss. 172 i 203. 
swoimi problemami egzystencjalnymi. Z powodu kryzysu religijnego w nowoczesnych społeczeństwach tak zwana bezdomność społeczna przyjęła jakby naturę metafizyczną, jest bezdomnością w kosmosie ${ }^{17}$.

Nowoczesne społeczeństwa stają się coraz bardziej świeckie, zarówno gdy idzie o porządek społeczny, jak i o motywację jednostkowe. Modernizacja i sekularyzacja są powiązane ze sobą empirycznie. Nowoczesne społeczeństwa o charakterze pluralistycznym przyspieszały proces „wypychania” religii na margines życia społecznego i zakwestionowania religijnych legitymizacji funkcjonujących jeszcze w sferze życia publicznego. Religia, podobnie jak i moralność motywowana religijnie stawały się sprawą prywatną ${ }^{18}$. W nowoczesnych społeczeństwach religia nie jest dominującą instancją podtrzymującą cały porządek społeczny, lecz tylko jedną z instancji pośród innych. Poważna część aktywności religijnych została zdominowana przez logikę ekonomii rynkowej ${ }^{19}$. Dla wielu wierzących nie istnieje ścisła dychotomia „albo - albo” między religijnym i sekularnym dyskursem, ale płynna konstrukcja, „nie tylko to, ale i tamto”. W kulturze pluralistycznej pewność wiary okazuje się dobrem rzadkim. Rzeczywistość wiary staje się wielowymiarowa i wielopostaciowa. Można wybierać - przeglądając różne oferty - spośród wielu możliwości, a nawet trzeba wybierać taką lub inną opcję religijną lub niereligijną (sekularną). Każdy może sobie zorganizować własny sposób wierzenia i praktykowania religii (alternatywna religijność lub duchowość).

Sekularyzacja - według Petera L. Bergera - oznacza taki proces, dzięki któremu sektory społeczeństwa i kultury wyzwalają się spod dominacji instytucji i symboli religijnych, co pociąga za sobą emigrację Kościołów chrześcijańskich z terenów uprzednio podlegających ich kontroli i wpływom (sekularyzacja społeczeństwa). Sekularyzacja ogarnia całość życia kulturalnego i twórczego, co prowadzi do zanikania treści religijnych w sztuce, filozofii, literaturze, nauce (sekularyzacja kultury). Sekularyzacja jest czymś więcej niż tylko procesem o charakterze społeczno-strukturalnym. Religia, a zwłaszcza Kościoły chrześcijańskie, stają się subsystemem funkcjonującym w oparciu o własne, specyficzne dla siebie reguły i normy. Nie pełnią w społeczeństwie roli nadrzędnej w postaci swoistego „świętego baldachimu"20.

Procesy sekularyzacyjne są wywołane przede wszystkim przez modernizację społeczną. Wyrażają się one między innymi w oddzieleniu Kościołów chrześcijańskich od państwa, w ograniczaniu dóbr ziemskich posiadanych przez Kościoły, wyemancypowaniu się spod wpływów kościelnych autorytetów w edukacji,

17 P.L. Berger, B. Berger, H. Kellner, Das Unbehagen in der Modernität, Campus Verlag, Frankfurt am Main-New York 1975, s. 159.

18 P.L. Berger, Trzeci świat jako idea religijna (fragmenty), „Pismo Literacko-Artystyczne” 1986, vol. 5, nr 6-7, s. 81.

19 P.L. Berger, Święty baldachim..., s. 186.

20 Ibidem, ss. 150-156. 
w ograniczaniu zawartości treści religijnych w sztuce, w powstaniu niezależnej od religii nauki i upowszechnianiu się świeckiej perspektywy w widzeniu świata. Sekularyzacja nie jest określana przez Bergera tylko jako proces wynikający z racjonalizacji współczesnej kultury zachodniej, ale jest wpisana do pewnego stopnia w dzieje rozwoju chrześcijaństwa i zakorzenienia w samej idei judeochrześcijańskiego, transcendentnego Boga. Mechanizmy racjonalizacji spowodowały przede wszystkim uniezależnienie się od religii różnych sfer życia społecznego: prawa, życia politycznego, gospodarki, edukacji i szkolnictwa ${ }^{21}$.

Proces sekularyzacji ma również stronę subiektywną. Sekularyzacja świadomości oznacza, że we współczesnym świecie przybywa ludzi patrzących na świat i na własne życie z pominięciem interpretacji religijnej. Jeżeli nawet można potraktować sekularyzację jako zjawisko globalne we współczesnych społeczeństwach, to jednak nie jest ono w nich rozłożone równomiernie. Wpływ sekularyzacji w znacznie większym stopniu dotyczy mężczyzn niż kobiet, ludzi w średnim wieku niż młodych i starszych, raczej mieszkających w miastach niż na wsi, częściej w obrębie klas społecznych związanych z nowoczesną produkcją przemysłową niż wykonujących tradycyjne zawody, częściej protestantów niż katolików²2.

Modernizacja społeczna przyniosła częściową sekularyzację, większą w jednych społeczeństwach, mniejszą w innych, ale dała również początek silnym ruchom antysekularyzacyjnym. Wraz z modernizacją zmienia się powoli utrwalony przez wieki tradycyjny układ życia społecznego. O ile dawniej religia była swoistym „losem” i „przeznaczeniem”, to w warunkach ponowoczesności staje się indywidualnym wyborem. Peter L. Berger twierdzi, że można dzisiaj wybierać wszystko, ale nie to, że chce się w ogóle wybierać. Wybieranie stało się swoistym imperatywem, nawet jeżeli jest ono współkształtowane przez rodzinne i społeczne środowiska ${ }^{23}$.

Dawne oferty życia traç̨ swoją wyłączność. Nowoczesność charakteryzuje się pluralizacją niemal wszystkich sfer ludzkiego życia. To, co było trwałe, staje się labilne, to, co było absolutnym nakazem, staje się ofertą wśród wielu innych możliwości. Reakcje ludzi na tę różnorodność równouprawnionych ofert i opcji są ambiwalentne. Pluralizm relatywizuje życie codzienne. Dla wielu ludzi współczesnych religia staje się swoistym „towarem konsumpcyjnym”, który można wybierać według potrzeb i gustów. Wraz z rozpadem tradycyjnych środowisk społecznych zmienia się nie tylko struktura społeczna, ale i poszerza się dla jednostek przestrzeń wolnych wyborów, również w odniesieniu do religii i Kościołów chrześcijańskich.

Sekularyzacja stanowi wynik rozpadu wiarygodności tradycyjnych definicji rzeczywistości. Zjawisko określane mianem pluralizmu jest społeczno-struktural-

${ }^{21}$ I. Borowik, Socjologia religii Petera L. Bergera, w: Święty baldachim. Elementy społecznej teorii religii, tłum. W. Kurdziel, Zakład Wydawniczy Nomos, Kraków 1971, ss. 18-19.

22 P.L. Berger, Sekularyzacja a problem wiarygodności religii, tłum. W. Kurdziel, w: Ateizm i irreligia oraz sekularyzacja, red. F. Adamski, Petrus, Kraków 2011, ss. 97-98.

${ }_{23}$ P.M. Zulehner, Ein neues Pfingsten. Ermutigung zu einem Weg der Hoffnung, Schwabenverlag, Ostfildern 2008, ss. 32-33. 
nym odpowiednikiem sekularyzacji świadomości. Sekularyzacja przyczynia się do demonopolizacji tradycji religijnych, a zatem ipso facto prowadzi do sytuacji pluralistycznej. Coraz trudniejsze jest podtrzymywanie tradycji religijnych jako niezmiennej prawdy ${ }^{24}$.

Sytuacja pluralistyczna pomnaża liczbę struktur wiarygodności konkurujących między sobą. Ipso facto, prowadzi to do relatywizacji ich treści religijnych. Konkretniej rzecz ujmując, treści religijne podlegają „dezobiektywizacji”, to jest zostają pozbawione swego dotychczas przyjmowanego w świadomości za oczywistość statusu obiektywnej realności. Stają się one „subiektywne” w dwojakim tego słowa znaczeniu: ich „realność” staje się „prywatną” sprawą jednostki, to jest zatraca właściwość oczywistej intersubiektywnej wiarygodności - zatem już „nie można mówić naprawdę” o religii. Ponadto ich „realność”, o ile jest jeszcze podtrzymywana przez jednostkę, rozumiana jest jako byt tkwiący raczej w jej świadomości aniżeli w faktyczności zewnętrznego świata - religia nie odnosi się już do kosmosu czy historii, lecz do indywidualnej Existenz lub psychologii ${ }^{25}$.

W sytuacji pluralistycznej relatywizują się konkurujące ze sobą światopoglądy, tracą one status oczywistości kulturowych. Pluralizm rodzi sekularyzację, jak i sekularyzacja rodzi pluralizm. Zarówno sekularyzacja, jak i pluralizm są dzisiaj zjawiskami ogólnoświatowymi. Według Petera L. Bergera nowoczesność jest nie tyle katalizatorem procesów sekularyzacyjnych, ile wielkim motorem pluralizmu.

Przez większą część historii ludzkość żyła we wspólnotach odznaczających się wysokim stopniem spójności wartości i przekonań. Nowoczesność podważa tę spójność: przez migrację i urbanizację, w wyniku których ludzie o różnych przekonaniach muszą się ustawicznie ścierać; przez powszechną edukację i masowe czytelnictwo, otwierające horyzonty wiedzy nieznane większości ludzi przednowoczesnych; i - najbardziej chyba dramatyczne - przez masową komunikację. Zmiany te zachodzą co najmniej od kilku stuleci, dziś jednak, za sprawą globalizacji, uległy przyspieszeniu na całym świecie.

\section{Berger dodaje:}

Niemal nie sposób już znaleźć miejsc nietkniętych przez dynamikę pluralizacyjną. Religia nie stanowi tu żadnego wyjątku. Zarówno w Ameryce Północnej, jak i Europie pluralizm przekształcił religię w obu perspektywach: instytucjonalnej i indywidualnej. Instytucje religijne, z których wiele przywykło do monopolu, muszą sobie radzić w warunkach konkurencji. W rezultacie wyłania się rynek religijny, w ramach którego jednostki mogą - wręcz muszą - dokonywać wyborów. Na poziomie indywidualnej świadomości oznacza to, że religia nie jest już czymś przezroczystym, lecz staje się podobnie zresztą jak coraz większa część kształtującej nas tradycji - przedmiotem namysłu i decyzji ${ }^{26}$.

\footnotetext{
${ }^{24}$ P.L. Berger. Święty baldachim, ss. 171-194.

${ }^{25}$ Ibidem, s. 201.

${ }^{26}$ P.L. Berger, Zachód z Bibliq w tle, ss. 5-6.
} 
W rzeczywistości religijnej przybywa wciąż alternatywnych opcji. To, co stanowiło kiedyś oczywistość kulturową, staje się problematyczne, może być wybrane lub zakwestionowane, lub nawet totalnie odrzucone.

Pluralizm wywiera znaczący wpływ na życie jednostek. „W miarę jak coraz większe obszary życia tracą swe niekwestionowane normy, jednostka musi rozpatrywać dostępne możliwości i dokonywać spośród nich wyboru. Modernizację można wręcz przedstawić jako gigantyczną zmianę kondycji ludzkiej z kondycji losu na kondycję wyboru”27. Powiększanie się obszarów życia, w których ludzie mogą podejmować wolne i autonomiczne decyzje, może być uznane za przejaw rozwoju społecznego. Pluralizm społeczno-kulturowy prowadzi niejednokrotnie do ambiwalencji, synkretyzmu, a także relatywizmu moralnego. Podważa on oczywistość przekonań i wartości ${ }^{28}$.

Peter L. Berger w XXI wieku zauważył, że wcześniej źle rozumiał związek pluralizmu i sekularyzacji.

Nowoczesność pluralizuje świat życia jednostek i w konsekwencji podkopuje wszystkie zakładane oczywistości. Pluralizacja, w zależności od innych czynników w konkretnej sytuacji, może, ale nie musi sekularyzować. Jeśli to twierdzenie wziąć za hipotezy, otwiera się przed nami fascynujące pole badań empirycznych. I znów prawdopodobnie owocne będzie tu porównanie Europy i Ameryki, przy czym Ameryka jawi się jako „przodujące społeczeństwo” nowoczesnego pluralizmu, pozostające jednakże daleko w tyle poza Europą, co się tyczy sekularyzacji [...]. Tak czy owak, powiedzieć, że przekonania religijne są raczej wybierane niż przyjmowane jako oczywistość, to nie to samo, co powiedzieć, iż nie są one już wyznawane. Mówiąc wprost, proponuję tezę, że pluralizm wpływa raczej na jak, a nie czy przekonań religijnych - a to coś całkiem różnego od sekularyzacji ${ }^{29}$.

Pogłębiający się pluralizm społeczno-kulturowy i strukturalna indywidualizacja stwarzają nie tylko nowe możliwości kształtowania własnej osobowości (czyli biografii „majsterkowicza”), ale i nowe uzależnienia i przymusy społeczne. Wyzwolenie się spod wpływów i nacisków społecznych w jednej dziedzinie może oznaczać podporządkowanie się innym uwarunkowaniom. Indywidualizacja nie musi oznaczać wyzwolenia się od wszelkich determinant, lecz jedynie ich transformacje. Procesy indywidualizacji wyborów wartości, wzorów zachowań i form życia, zapoczątkowane w nowoczesności, rozwijają się w epoce ponowoczesnej, współcześnie nabierają do pewnego stopnia wymiarów globalnych. W społeczeństwach ponowoczesnych dokonuje się - z powodu znacznego pluralizmu społecz-

${ }^{27}$ P.L. Berger, Między relatywizmem i fundamentalizmem, tłum. R. Lewandowski, „W drodze” 2007, nr 9, ss. 10-11.

${ }^{28}$ P.L. Berger, Zasada wątpliwości. Poza relatywizmem i fundamentalizmem, tłum. T. Bieroń, „Dziennik” 2008, nr 93 (dodatek „Europa”, nr 16), ss. 14-15.

${ }^{29}$ P.L. Berger, Refleksje o dzisiejszej socjologii religii, s. 95. 
nego i kulturowego - proces problematyzacji przekonań religijnych i moralnych. Znikła dawna jednolitość systemów aksjologicznych ${ }^{30}$.

Europa Zachodnia, która jawi się jako najbardziej zsekularyzowany kontynent, jest przypadkiem szczególnym na religijnej mapie świata. Jest ona bardziej zdechrystianizowana niż zsekularyzowana. Ci, którzy przyjmują ścisłą korelację między modernizacją i sekularyzacją, uznają sekularyzację Europy Zachodniej za przypadek normalny. Europa przoduje w procesach sekularyzacji, Ameryka wykazuje w tym względzie pewne opóźnienie. Zsekularyzowana Europa jest pewnym wyjątkiem we współczesnym świecie, który to fenomen wymaga wyjaśnienia.

W Europie Zachodniej tradycyjne Kościoły chrześcijańskie były traktowane przez wielu badaczy trendów religijnych w warunkach przyspieszonej modernizacji społecznej jako „przegrywający” na wolnym rynku idei religijnych. Tracą one także semantyczny monopol w określaniu tego, co religijne. Jednostki we własnym zakresie określają intensywność i trwanie swoich zaangażowań religijnych i parareligijnych (sami przygotowują swój „religijny coctail”). Każdy osobiście staje się ekspertem w sprawach religijnych („,kto jest Bogiem i kim jest Bóg, określam ja sam”). Według Bergera świat współczesny jest widownią zmasowanej sekularyzacji, ale tak samo areną ruchów przeciwnych. Religia pozostaje tematem światowym, Europa Zachodnia jest z punktu widzenia socjologii przypadkiem szczególnym ${ }^{31}$.

Peter L. Berger zauważa:

Nowoczesność być może nie przyniosła ze sobą upadku religii, ale doprowadziła do jej przekształcenia. Jedną z głównych tego przyczyn moim zdaniem oddzielenia tych sfer życia, które wcześniej pozostawały złączone. Dobrym przykładem jest oddzielenie religii i medycyny - podstawową reakcją na chorobę jest dziś wezwanie lekarza, a nie odprawianie modłów. Nawet jeśli chory papież odwołuje się do pomocy medycyny, nie neguje tym samym swojej religijności, ponieważ medycyna stała się oddzielnym i niezależnym obszarem. Takiemu rozdzieleniu kolejnych sfer życia towarzyszyło oczywiście instytucjonalne zróżnicowanie się społeczeństwa. O zjawisku sekularyzacji możemy więc mówić w tym sensie, ale z pewnością nie jesteśmy dziś świadkami upadku religii [...]. Skończyła się epoka, kiedy socjologowie religii automatycznie łączyli modernizację z sekularyzacją, dziś okazuje się, że wyjątkiem w skali globalnej nie jest Ameryka - ze swoim połączeniem nowoczesności i religijności, ale Europa - ze swoim eurosekularyzmem ${ }^{32}$.

Według Petera L. Bergera są jakby dwa ogniska sekularyzacji na religijnej mapie świata. Po pierwsze, jest to niewielka, ale bardzo wpływowa grupa intelektualistów, których najogólniej można by zdefiniować jako ludzi Zachodu, dobrze wykształ-

${ }^{30}$ P.L. Berger, Pytania o wiarę. Sceptyczna zachęta do chrześcijaństwa, tłum. J. Łoziński, Instytut Wydawniczy Pax, Warszawa 2007, ss. 17-18.

${ }_{31}$ P.L. Berger, Alternatywne nowoczesności. Euroświeckość i amerykańska religia, tłum. A. Bielik-Robson, „Fakt” 2005, nr 220 (dodatek „Europa”, nr 38), ss. 5-7.

${ }^{32}$ Religia i nowoczesność. Rozmowa z amerykańskim socjologiem religii Peterem Bergerem, „Europa. Miesięcznik Idei” 2012, nr 5, s. 24. 
conych, zwłaszcza z obszaru nauk humanistycznych i społecznych, działających w przestrzeni międzynarodowej. Po drugie, jest to Europa Zachodnia i Centralna, w której procesy sekularyzacyjne są zaawansowane i gdzie do pewnego stopnia teza sekualaryzacyjna potwierdza się, przynajmniej jeszcze niedawno temu. Pytanie, dlaczego Europa jest zsekularyzowana, jest pytaniem fascynującym ${ }^{33}$. Procesy desekularyzacyjne powoli zaczynają pojawiać się i w Europie Zachodniej, ale są one tu jeszcze czymś zagadkowym i trudno rozpoznawalnym. Coraz mniej badaczy, w tym socjologów, wierzy w swoisty automatyzm „modernizacja społeczna - sekularyzacja”. Nie brakuje i tych, którzy tezę o „powrocie religii” w odniesieniu do Europy Zachodniej traktują jako mit, którego nie potwierdzają „twarde” dane empiryczne ${ }^{34}$.

Można by poprzestać za Peterem L. Bergerem na prostej definicji sekularyzacji jako procesu, dzięki któremu sektory społeczeństwa i kultury wyzwalają się spod dominacji instytucji i symboli religijnych. Sekularyzacja nie jest tylko procesem o charakterze społeczno-strukturalnym, związanym z dyferencjacją społeczną.

Ogarnia całość życia kulturalnego i twórczego i może być obserwowana na przykładzie zanikania religijnych treści w sztuce, w filozofii, w literaturze oraz - co jest najbardziej znaczące - w rozwoju nauki jako autonomicznej, zupełnie świeckiej wizji świata. Ponadto zakłada się tu, że proces sekularyzacji ma również stronę subiektywną. Tak jak istnieje sekularyzacja społeczeństwa i kultury, istnieje sekularyzacja świadomości. Mówiąc zwyczajnie oznacza to, że współczesny Zachód produkuje coraz więcej jednostek patrzących na świat i na swoje własne życie bez dobrodziejstwa interpretacji religijnej ${ }^{35}$.

Istnienie wielu definicji rzeczywistości religijnej i kościelnej, z którymi styka się człowiek, powoduje labilność w kwestiach wiary.

Sytuacja pluralistyczna stawia instytucje religijne przed dwiema opcjami mającymi charakter typów idealnych. Instytucje te mogą się więc przystosować do sytuacji, brać udział w pluralistycznej grze wolnych religijnych przedsięwzięć i rozwiązywać najlepiej jak tylko potrafią problem wiarygodności w drodze modyfikacji swoich produktów zgodnie z oczekiwaniem konsumentów. Mogą one też odmówić przystosowania się, schronić się za jakimikolwiek społeczno-religijnymi strukturami - podtrzymywanymi lub skonstruowanymi przez siebie - i dalej w granicach możliwości wyznawać stare „prawdy”, jak gdyby nic się nie stało. [...] Problemy te łącznie tworzą „kryzys teologii” i „kryzys Kościoła” we współczesnym społeczeństwie ${ }^{36}$.

${ }^{33}$ P.L. Berger, Secularization and de-secularization, w: Religious in the Modern World. Traditions and transformations, red. L. Woodhead, P. Fletcher, H. Kawanami, D. Smith, London 2002, ss. 291-329.

${ }^{34}$ D. Pollack, Religion und Moderne: Theoretische Überlegungen und empirische Beobachtungen, w: Moderne und Religion. Kontroversen um Modernität und Säkularisierung, Hrsg. von Ulrich Willems, Detlef Pollack, Helene Basu, Thomas Gutmann, Ulrike Spohn, Transcript Verlag, Bielefeld 2013, s. 318.

${ }^{35}$ P.L. Berger. Święty baldachim..., s. 150.

${ }^{36}$ Ibidem, s. 202. 
Wiara religijna przestaje być sprawą losu, staje się sprawą indywidualnego wyboru czy preferencji. Wiąże się ze wzrastającą autonomią oraz uniezależnianiem się od różnego rodzaju środowisk społecznych. Dokonuje się to w warunkach, w których religijne legitymizacje utraciły swoją wiarygodność nie tylko w kręgach niektórych intelektualistów, ale i w szerokich masach całego społeczeństwa (kryzys wiarygodności religii).

Subiektywnie rzecz ujmując - zwykły człowiek staje się niezdecydowany, gdy idzie o sprawy religijne. Obiektywnie rzecz ujmując - zwykły człowiek styka się z szeroką gamą sposobów definiowania rzeczywistości. Są to definicje o charakterze religijnym i niereligijnym, które rywalizują między sobą (przynajmniej w tym, aby na nie zwrócono uwagę), natomiast żadna z nich nie jest w stanie zmusić człowieka do przyjęcia jej za własną. Innymi słowy, zjawisko określane mianem „pluralizmu” jest społeczno-strukturalnym odpowiednikiem sekularyzacji świadomości. Związek ten zachęca do analizy socjologicznej ${ }^{37}$.

Paradygmat globalnej sekularyzacji został częściowo zakwestionowany w końcu lat 80. XX wieku, zwłaszcza zaś linearny charakter procesów sekularyzacyjnych. Religia nie znika z życia społecznego, lecz wykazuje wiele zdolności dopasowania się do nowych warunków społeczno-kulturowych. Socjologowie - przynajmniej niektórzy - zauważają, że nie następuje całkowita sekularyzacja i nie nastąpi, i że religii nie da się wyrugować z życia społecznego. Myślenie o totalnej nieuchronności sekularyzacji odchodzi w zapomnienie. Tak zwana epoka świecka, o której pisze Charles Taylor, oznacza jedynie przejście od życia religijnego, mającego swój środek ciężkości w wielkich narodowych Kościołach chrześcijańskich, do świata olbrzymiej różnorodności duchowych i religijnych poszukiwań, do coraz większego duchowego pluralizmu, obejmującego też niewiarę. Do wiary religijnej ludzie dochodzą różnymi drogami ${ }^{38}$.

37 Ibidem, s. 173.

${ }^{38}$ Filozofo czasach sekularyzacji. Charles Taylor w rozmowie z Mateuszem Burzykiem i Mirosławem Jędrzejkiem, „Znak” 2019, nr 12, ss. 29-31; J. Mariański, Europa bez Boga? Między sekularyzacjq i desekularyzacjq w społeczeństwie postsekularnym, w: Janusz Mariański. Doctor Honoris Causa Universitatis Silesiensis, Wydawnictwo Uniwersytetu Śląskiego, Katowice 2019; Ch.J. Knight, Charlesa Taylora A Secular Age: impuls apofatyczny, tłum. J. Adamko, w: Charlesa Taylora wizja nowoczesności. Rekonstrukcje i interpretacje, red. Ch. Garbowski, J.P. Hudzik, J. Kłos, Oficyna Wydawnicza Łośgraf, Warszawa 2012, s. 119; P.L. Berger, Religion und europäische Integration. Bemerkungen aus amerikanischer Sicht, „Transit. Europäische Review” 2004, nr 27, ss. 107-117; M. Sroczyńska, Życie „na przemiał“ a religia - wyzwanie dla socjologa, w: Religia a gospodarka. Suplement, red. S. Partycki, Wydawnictwo KUL, Lublin 2005, ss. 54-58. 


\section{Teoria desekularyzacji w ofensywie}

Według Petera L. Bergera socjologowie zbyt pospiesznie utożsamili sekularyzację z pluralizmem oraz sekularyzm z pluralizmem i uznali, że nowoczesność (modernizacja społeczna) pociąga za sobą w nieuchronny sposób upadek religii. Faktem natomiast są upowszechniające się procesy pluralizacji społeczno-kulturowej, które sprawiają, że ludzie żyją dzisiaj w całkowicie nowej sytuacji, nacechowanej wielością konkurencyjnych przekonań i stylów życia. Nie pozostaje to bez wpływu na religijność ludzi współczesnych ${ }^{39}$.

Peter L. Berger, w latach 60. i 70. XX wieku zwolennik teorii globalnej sekularyzacji, twierdzi dzisiaj, że teorie sekularyzacji są w gruncie rzeczy wielką pomyłką (falsyfikacja teorii). Nie żyjemy w zsekularyzowanym świecie, lecz w świecie „ponownie zaczarowanym”, o odradzającej się religijności w skali światowej. Niemal wszędzie przybywa ruchów konserwatywnych, ortodoksyjnych i tradycyjnych, obserwujemy ożywienie postaw zdecydowanie religijnych. „Współczesny świat jest więc ogromnie religijny i nie ma nic wspólnego ze zsekularyzowanym światem, jaki przepowiadało (czy to z radością, czy z przygnębieniem) tak wielu badaczy nowoczesności”. Autor powołuje się na sytuację w Ameryce Północnej, gdzie pomimo bardzo zaawansowanych procesów modernizacyjnych religia odznacza się wyjątkową żywotnością. Nie wolno zapominać o renesansie islamu w wielu krajach świata, o ruchach ewangelikalnych protestantyzmu we wschodniej i południowej Azji, Ameryce Łacińskiej, Afryce oraz o wielu innych nowych ruchach religijnych i quasi-religijnych. Odrodzenie religijne w różnych krajach ma bardzo populistyczny charakter, nie obejmuje w zasadzie tak zwanych elit kulturalnych ${ }^{40}$.

Teza, że modernizacja z konieczności oznacza upadek religii, została - według Petera L. Bergera - empirycznie sfalsyfikowana. W wielu krajach współczesnego świata religijność nie słabnie. Sprzyja temu pluralizm światopoglądów i systemów wartości. Nowoczesność (modernizacja społeczna) nie powoduje, że Bóg jest martwy (umiera), lecz że jest wielu bogów, czyli rozwijają się rozmaite nurty wiary religijnej. W warunkach upowszechniającego się pluralizmu wiara staje się kwestią osobistej decyzji. Także w Europie te procesy będą się nasilać, w przyszłości upodobni się ona pod tym względem do Stanów Zjednoczonych ${ }^{41}$.

${ }^{39}$ P.L. Berger, Nach dem Niedergang der Säkularisierungstheorie, Centrum für Religion und Moderne - Westfälische Wilhelms-Universität Münster, Münster 2013, s. 2.

${ }^{40}$ P.L. Berger, Further Thoughts on Religion and Modernity, „Society” 2012, 49, ss. 313-316.

${ }^{41}$ P.L. Berger, Auf der Suche nach einer Friedensformel: Replik, w: Nach dem Niedergang der Säkularisierungstheorie, Centrum für Religion und Moderne - Westfälische Wilhelms-Universität Münster, Münster 2013, ss. 40-41; Z. Drozdowicz, Wiara i niewiara w Boga amerykańskich uczonych, „Przegląd Religioznawczy” 2019, nr 2, ss. 3-17. 
Peter L. Berger ocenia jako błędne twierdzenie, że żyjemy w zsekularyzowanym świecie:

Dzisiejszy świat, z pewnymi wyjątkami, do których wkrótce powrócę, jest bardzo religijny, a w niektórych przypadkach bardziej niż kiedykolwiek wcześniej. Oznacza to, że cała masa literatury wytworzonej przez historyków i badaczy życia społecznego, skrótowo określanej mianem teorii sekularyzacji, jest od podstaw fałszywa. W początkach własnej pracy naukowej przyczyniłem się do rozwoju tej literatury. Byłem w dobrym towarzystwie - większość socjologów religii podzielała ten pogląd - zresztą mieliśmy ważne powody, by przy nim trwać. Niektóre z prac dawniej powstałych nie straciły na aktualności ${ }^{42}$.

Analizy socjologiczne i tworzone przez socjologów teorie zawsze podążają za zmieniającą się rzeczywistością społeczną i religijną. Teorie socjologiczne, by były trafne, powinny w samym modelu uwzględniać możliwości, iż „sytuacja może ulec zmianie, a kierunek tych zmian może być nieoczekiwany. Potencjalne zmiany muszą stanowić integralną część teorii, a nie nadprogramowy dodatek”*33. Grace Davie, a jeszcze bardziej Peter L. Berger, wyraźnie mówią o procesach desekularyzacji (Entsäkularisierung). Teoria sekularyzacji wywodząca się z Oświecenia i spopularyzowana w latach 50. i 60. ubiegłego wieku, wskazująca, że modernizacja społeczna z konieczności prowadzi do upadku religii zarówno w społeczeństwie, jak i w świadomości ludzi, okazała się błędna ${ }^{44}$.

Peter L. Berger przez wiele lat był zwolennikiem teorii sekularyzacji ${ }^{45}$. Według jego wcześniejszych założeń modernizacja prowadziła do pluralizmu, ten z kolei do sekularyzacji. Pluralizm nie zawsze eliminował wiarę religijną (wierzenia), ale stwarzał niekorzystne warunki dla krzewienia wiary. Wierzący stawali się tak zwaną kognitywną mniejszością. W ostatnich dwóch dekadach Berger odszedł od teorii sekularyzacji, przestała ona być dla niego ważna. Modernizacja co prawda prowadzi do pluralizmu, ale niekoniecznie do sekularyzacji. W nowoczesnych, pluralistycznych warunkach jednostki mogą wybierać spośród wielu religii, mogą też wybierać opcję niereligijną. Większość ludzi wybiera jednak jakąś religię. Teoria sekularyzacji głosiła, że będzie coraz mniej bogów, a teoria pluralizmu wskazuje na to, że bogów przybywa. Pierwsza głosiła, że nowoczesność będzie wiekiem

${ }^{42}$ P.L. Berger, The Desecularization of the World..., s. 2.

${ }^{43}$ G. Davie, Socjologia religii, tłum. R. Babińska. Zakład Wydawniczy Nomos, Kraków 2010, s. 343.

${ }^{44}$ W. Eßbach, Religionssoziologie. Entfesselter Markt und Artifizielle, Lebenswelt als Wiege neuer Religionen, Bd. 2, Wilhelm Fink Verlag, Paderborn 2019; J. Mariański, Sekularyzacja, w: Leksykon socjologii religii. Zjawiska - badania - teorie, red. M. Libiszowska-Żółtkowska, J. Mariański, Verbinum Wydawnictwo Księży Werbistów, Warszawa 2004, ss. 364-369.

${ }^{45}$ P.L. Berger, Zur Dialektik von Religion und Gesellschaft, Fischer Verlag, Frankfurt am Main 1967; P.L. Berger, Modernizacja jako uniwersalizacja herezji, tłum. B. Mikołajewska, w: Religia a życie codzienne, t. 1, red. H. Grzymała-Moszczyńska, Instytut Religioznawstwa Uniwersytetu Jagiellońskiego, Kraków 1990, ss. 13-46. 
ateizmu, druga - ku zaskoczeniu wielu - podkreśla, że nowoczesność staje się wiekiem pluralizmu religijnego ${ }^{46}$.

Według Petera L. Bergera socjologowie zbyt pospiesznie utożsamamiali sekularyzację z pluralizmem oraz sekularyzm z pluralizmem i uznali, że nowoczesność (modernizacja społeczna) pociąga za sobą w nieuchronny sposób upadek religii. Faktem natomiast są upowszechniające się procesy pluralizacji społeczno-kulturowej, które sprawiają, że ludzie żyją dzisiaj w całkowicie nowej sytuacji, nacechowanej wielością konkurencyjnych przekonań i stylów życia. Nie pozostaje to bez wpływu na religijność ludzi współczesnych ${ }^{47}$.

Teorie sekularyzacji wskazywały na specyficznie religijne następstwa procesów modernizacyjnych (dekompozycja religijności kościelnej), religię traktowano jako zmienną zależną od czynników społeczno-kulturowych. Sekularyzacja oznaczała stopniowy upadek religii. Nie można co prawda odłożyć teorii sekularyzacyjnych ad acta, należy je jednak traktować ze znaczną ostrożnością. Według Petera L. Bergera dla opisania miejsca i roli religii we współczesnym świecie wymaga się znacznie więcej, niż może zaoferować teoria sekularyzacji. Należy odwołać się do teorii pluralizacji. Obydwie teorie dają lepszą szansę zrozumienia przemian religii w warunkach nowoczesności ${ }^{48}$.

Berger nie kwestionuje sekularyzacyjnego wpływu pluralizmu społeczno-kulturowego, ale uważa, że nie jest on na tyle silny, by zniszczyć religię. Co więcej, twierdzi, że „świat z pewnymi godnymi uwagi wyjątkami [...] jest tak samo religijny, jak zawsze, a gdzieniegdzie nawet bardziej niż kiedykolwiek. Nie oznacza to jednakże, że nie istnieje coś takiego, jak sekualryzacja, tylko że zjawisko to w żadnym wypadku nie jest bezpośrednim i nieuchronnym skutkiem nowoczesności” ${ }^{49}$. Berger przywołuje niezwykle silny wzrost liczby ruchów religijnych, nierzadko o daleko sięgających konsekwencjach społecznych i politycznych. W tym kontekście mówi o odradzaniu się islamu, zarówno w krajach islamskich, jak i w muzułmańskich diasporach, a także o rozkwicie ewangelikalizmu, zwłaszcza w jego zielonoświątkowej odmianie w Ameryce Łacińskiej. Silne ożywienie religijne dostrzega się wśród katolików (zwłaszcza w krajach rozwijających się), wśród protestantów (zwłaszcza w Rosji), wśród żydów (w Izraelu i diasporze),

${ }^{46}$ P.L. Berger, Adventures of an accidental Sociologist. How to explain the world without becoming a bove, Prometheus Books, New York 2011, ss. 136-139; T. Schmidt-Lux, Peter L. Berger: religia jako święty kosmos, w: Filozofia religii (od Schleiermachera do Eco), red. V. Drehsen, W. Gräb, B. Weyel, tłum. L. Łysień, Wydawnictwo WAM, Kraków 2008, ss. 207-215.

${ }^{47}$ P.L. Berger, Nach dem Niedergang der Säkularisierungstheorie, s. 2; T. Adamczyk, Desekularyzacja w warunkach globalizacji, w: Religia i religijność w warunkach globalizacji, red. M. Libiszowska-Żółtkowska, Zakład Wydawniczy Nomos, Kraków 2007, ss. 71-73.

${ }^{48}$ P.L. Berger, Sehnsucht nach Sinn. Glauben in einer Zeit der Leichtgläubigkiet, Kamphausen J. Verlag, Frankfurt am Main 1994, s. 43.

${ }^{49}$ P.L. Berger, Refleksje o dzisiejszej socjologii religii, s. 91. 
wśród hinduistów i buddystów. „Mówiąc wprost, większość świata bucha religijnym żarem"50.

W wywiadzie udzielonym 29 października 1997 roku Peter L. Berger raz jeszcze oświadczył, że to, co w latach 60 . ubiegłego wieku napisał on i wielu innych socjologów na temat sekularyzacji, było błędne, zwłaszcza teza, że wraz ze wzrostem nowoczesności postępuje sekularyzacja, choć istniały pewne przesłanki skłaniające do przyjęcia takiej tezy. Współczesny świat - w swej znacznej części - nie jawi się jako zsekularyzowany, ale wykazuje wiele objawów religijności (łącznie z USA). Europa Zachodnia jest raczej wyjątkiem i pytanie, dlaczego jest ona inna, stanowi interesujący problem z socjologicznego punktu widzenia ${ }^{51}$. Swój manifest antysekularyzacyjny podtrzymał Berger w swoim wystąpieniu 7 maja 2012 roku na uniwersytecie w Münster i w dyskusji po swoim referacie ${ }^{52}$.

Coraz rzadziej socjologowie twierdzą, że proces sekularyzacji obejmuje wszystkie dziedziny życia ludzkiego, że jest procesem jednokierunkowym, spontanicznym i nieodwracalnym. Niektórzy badacze społeczni mówią nawet o „pożegnaniu z sekularyzowanym światem”, o „powtórnym zaczarowaniu świata”, o megatrendzie spirytualizacji, o procesach antysekularyzacyjnych, o odsekularyzowaniu życia publicznego itp. Socjologowie nie są już tak pewni jak dawniej nawet tego, że Kościół ludowy „jest skończony” lub że znajduje się w fazie utrwalonego, radykalnego kryzysu.

W wywiadzie opublikowanym w 2001 roku Berger wyjaśniał swoje osobiste powody odejścia od teorii sekularyzacji. Zmiana stanowiska nie wynikała z racji teologicznych (pozostał on na pozycjach liberalnego protestantyzmu), lecz socjologicznych. Dane empiryczne - według niego - coraz częściej kwestionują (falsyfikują) teorię sekularyzacji. Jeżeli nawet rezultatem modernizacji społecznej jest pluralizm, to nie w tym samym stopniu co sekularyzm (Ameryka jest tu najlepszym przykładem jako intensywnie pluralistyczne społeczeństwo i słabo zsekularyzowane). Związek modernizacji i sekularyzacji nie ma charakteru koniecznościowego. Należy raczej wyjaśnić, dlaczego w Europie te dwa procesy są ze sobą do pewnego stopnia powiązane. Eurosekularyzm wymaga wyjaśnienia z perspektywy socjologicznej. Należy także podkreślić, że niekiedy utożsamia się - w sposób nieuprawniony - osłabienie (zanik) religijności kościelnej z osłabieniem (zanikiem) religijności w ogóle. Nowe formy niekościelnej (pozakościelnej) i zindywidualizowanej religijności powinny być w szerszym zakresie przedmiotem badań socjologicznych ${ }^{53}$.

${ }^{50}$ Ibidem, s. 91.

${ }^{51}$ Epistemological Modesty: an Interview with Peter Berger, „Christian Century” 1997, vol. 114, nr 30, ss. 972-977.

${ }_{52}$ P.L. Berger, Nach dem Niedergang der Säkularisierungstheorie, s. 8.

${ }^{53}$ Persönliches und Gesellschaftliches. Ein Gespräch mit Peter L. Berger, Emil Brix und Manfred Prisching, w: Gesellschaft verstehen. Peter L. Berger und die Soziologie der Gegenwart, Hrsg. von M. Prisching, Passagen Verlag, Wien 2001, s. 161. 
Peter L. Berger mówi wprost o desekularyzacji i podkreśla, że we współczesnym świecie nie tyle widać sekularyzację, ile raczej potężną eksplozję żarliwych ruchów religijnych. Wskazuje na wzrost znaczenia religii we współczesnym świecie. Islam i chrześcijaństwo rozszerzają swoje wpływy w Afryce, a tak zwane ruchy „przebudzeniowe” z USA rozwijają się w Ameryce Południowej. Wskazuje on na ruchy zielonoświątkowców, zwłaszcza w Ameryce, ale i w Afryce oraz w niektórych regionach Azji. Ich liczebność ocenia się na 400 milionów (przyrost religijności niespotykany w historii). Wzrasta liczba innych ugrupowań chrześcijańskich (na przykład Mormonów). Odrodzenie islamu dokonuje się na całym świecie. Miliony ludzi dostrzegają w islamie religię, która daje sens i kierunek w życiu. Wykorzystywanie islamu do prześladowań innych religii czy wykorzystywanie go do polityki jest już inną kwestią.

W Indiach zyskuje na znaczeniu neohinduizm, w postsocjalistycznych Chinach - buddyzm, taoizm i tradycje magiczne oraz konfucjanizm, zarówno jako religia, jak i system etyczny. W Japonii mieszają się elementy tradycji zen-buddyzmu, chrześcijaństwa i tradycji magicznych. W Rosji wiele uznania zyskuje Kościół prawosławny. Tradycyjny judaizm przeżywa swoje odrodzenie religijne w Izraelu i Ameryce. W odniesieniu do katolicyzmu wskazuje się między innymi wielkie światowe dni młodzieży, pielgrzymki do dawnych i nowych miejsc kultu, dynamiczny rozwój ruchów i stowarzyszeń katolickich, odnowa duchowości chrześcijańskiej wokół zakonów i wiele innych nowych przejawów wrażliwości religijnej. Ożywienie religijne dotyczy wszystkich wielkich religii we współczesnym świecie ${ }^{54}$.

W Europie co prawda teza sekularyzacyjna - według Bergera - jest zasadna, a związek sekularyzacji z nowoczesnością jest wyraźny, ale z tego nie wynika, że każde zmodernizowane społeczeństwo, lub takie, które chce się modernizować, musi rozstać się z religią. Europejski projekt areligijnej modernizacji nie realizuje się we współczesnym świecie. W wielu krajach świata, nie tylko w USA, religia i modernizacja harmonizują ze sobą, a religia przeżywa wyraźny rozwój. Kluczem wyjaśniającym jest tu teza pluralizmu, czyli wielość form i grup religijnych. Berger, podobnie jak wielu socjologów amerykańskich, uważa, że pluralizm i konkurencyjność między organizacjami religijnymi na wolnym rynku światopoglądowym przyczyniają się do trwania, a nawet wzrostu religijności. Im więcej jest konkurencyjności między religiami, tym ludzie są bardziej religijni. Brak konkurencyjności między religiami w Europie jest jedną z ważnych przyczyn wyjaśniających sekularyzację na kontynencie europejskim. W Europie zaznacza się kryzys kościelnie zsocjalizowanych aktywności religijnych, ale poza Kościołami chrześcijańskimi rozwijają się różne formy duchowości i ruchy charyzmatyczne. Teza, że nowoczesność prowadzi do zmierzchu religii, staje się coraz mniej wiarygodna. Sprzyja ona

${ }^{54}$ P.L. Berger, Refleksje o dzisiejszej socjologii religii, ss. 89-100; R. Boguszewski, Religijność i moralność w społeczeństwie polskim: zależność czy autonomia? Studium socjologiczne, Wydawnictwo Adam Marszałek, Toruń 2012, ss. 40-47. 
bez wątpienia pluralizacji sceny religijnej, a ta ma pozytywny wpływ na sytuację religijną współczesnych społeczeństw ${ }^{55}$.

Współczesny świat nie jest zsekularyzowany, przeciwnie, mamy do czynienia z masywną eksplozją religijną i to niemal we wszystkich tradycjach religijnych. Europa Zachodnia i Środkowa, być może także Australia, to wyjątki, gdzie teza o bezpośrednim związku modernizacji i sekularyzacji wydaje się potwierdzona. W skali globalnej nie znajduje to potwierdzenia. USA nie są mniej nowoczesne niż Niemcy, a religijność jest tam o wiele wyższa. Pomimo prawnego rozdziału Kościoła i państwa, lub - religii i państwa - religia odgrywa wciąż ważną rolę w życiu publicznym (tak zwana religia cywilna). Mimo silnych oddziaływań zsekularyzowanych elit kulturalnych (tak zwana inteligencja) społeczeństwo amerykańskie wykazuje wiele oznak żywotności religijnej ${ }^{56}$.

Według Petera L. Bergera i Antona C. Zijdervelda świat współczesny jest religijny, istnieją jednak dwa wyjątki - jeden ma charakter geograficzny, drugi socjologiczny. Europa Zachodnia i Środkowa - to jedyna ważna część świata, w której teoria sekularyzacji wydaje się prawdopodobna. Chociaż w Europie odnotowano znaczący spadek religijności związanej z Kościołami chrześcijańskimi, to równocześnie można dostrzec najróżniejsze rodzaje aktywności religijnych, od rozmaitych postaci New Age, do ruchów charyzmatycznych. Ponowne pojawienie się islamu w Europie doprowadziło do ożywienia dyskusji na temat judeochrześcijańskich korzeni tego kontynentu. Drugi wyjątek stanowi szczupła, ale znacząca klasa intelektualistów reprodukująca globalny sekularyzm. Mimo tych dwóch znaczących wyjątków nie można dzisiaj już podtrzymywać tezy, że nowoczesność siłą rzeczy prowadzi do upadku religii. Nowoczesność prowadzi nie do sekularyzmu, lecz do różnorodności. Różnorodność zwiększa zdolność człowieka do dokonywania wyborów spośród różnych światopoglądów. Teoria sekularyzacji nie sprawdziła się, ponieważ zakładała, że wybory te będą mieć niemal zawsze charakter świecki, w rzeczywistości mogą mieć one równie dobrze charakter religijny. Być może wybrana religia będzie mieć charakter nieco mniej trwały i będzie słabsza, ale nie musi. Religia nie znika pod wpływem modernizacji, trwa i przyjmuje wciąż nowe formy ${ }^{57}$.

${ }_{55}$ P.L. Berger, A.C. Zijderveld, Pochwała wątpliwości. Jak mieć przekonania i nie stać się fanatykiem, tłum. S. Baranowski, vis-á-vis Etiuda, Kraków 2010, ss. 12-15; A. Wójtowicz, Doctrina sacra, ezoteryzm - oswajanie tajemnicy, w: Pluralizm religijny i odmiany ezoteryzmu, red. A. Wójtowicz, W. Klimski, Wydawnictwo Naukowe Uniwersytetu Kardynała Stefana Wyszyńskiego w Warszawie, Warszawa 2019, ss. 37-110.

${ }^{56}$ P.L. Berger, W. Weiße, Im Gespräch: Religiöse Pluralität und gesellschaftlicher Zusammenhalt, w: Religiöse Differenz als Chance? Positionen, Kontroversen, Perspektiven, Hrsg. von Wolfram Weiße, Hans-Martin Gutmann, Waxmann, Münster 2010, ss. 17-19; W. Weiße, Die moralischen Grenzen religiöser Pluralität. Grundidee und Strategie eines unvollendeten Großprojektes von Peter L. Berger, w: Religiöse Differenz als Chance? Positionen..., Hrsg. von Wolfram Weiße, Hans-Martin Gutmann, s. 35-42.

57 P.L. Berger, A.C. Zijderveld, Pochwała wątpliwości..., ss. 21, 31-32. 
Berger odrzuca tezę, że modernizacja pociąga za sobą w sposób nieuchronny spadek religijności, nie tylko w sferze instytucjonalnego porządku, ale i w świadomości jednostek. Na zmianę swojego stanowiska Berger potrzebował - jak sam wyznaje - 20 lat. Świat współczesny nie jest zsekularyzowany, lecz charakteryzuje się znaczną witalnością religijną. Modernizacja nie prowadzi automatycznie do sekularyzacji społeczeństwa, lecz do pluralizmu (Pluralität). W warunkach modernizacji powstają sytuacje, w których ludzie są konfrontowani z różnymi światopoglądami, religiami, systemami wartości i wzorami zachowań. To, co było dawniej swoistą oczywistością, staje się przedmiotem wyboru. Pluralizm pociąga za sobą relatywizację. Światopoglądy, systemy wartości i wzory zachowań nie mają już rangi oczywistości. Odnosi się to także do innych poznawczych i normatywnych definicji rzeczywistości, ale religii dotyczy to w sposób szczególnie wyraźny i daleko idący. Proces relatywizacji dotyczy całego świata i jest konsekwencją pluralizacji. Pluralizacja i relatywizacja, a nie sekularyzacja są najbardziej ewidentną cechą czasów współczesnych - twierdzi obecnie Peter L. Berger ${ }^{58}$.

Coraz częściej mówi się na gruncie nauk społecznych o swoistym „renesansie” potrzeb religijnych. Ponowoczesny człowiek poszukuje różnych form zaspokojenia swoich potrzeb religijnych, tyle że nie zawsze w zinstytucjonalizowanych religiach i Kościołach, lecz bardziej w sferze „odkościelnionej”, niezwiązanej i sprywatyzowanej religijności, będącej nierzadko kompilacją różnych systemów religijnych i światopoglądowych. To, że religia może zyskiwać na znaczeniu, traktowano do niedawna jako zwykłe myślenie życzeniowe teologów i hierarchów Kościołów chrześcijańskich, obecnie część socjologów przyjmuje tezę desekularyzacyjną (formułowaną rozmaicie) jako prawdopodobną. Wyrażają oni pogląd, że religia jest wciąż znaczną siłą społeczną, chociaż występuje w nowych, zmodernizowanych formach. Często przejawia się w „zdryfowanych” kształtach i poza oficjalnymi strukturami kościelnymi ${ }^{59}$, jako wiara bez silnych więzi z Kościołem, przynależność bez wiary (formalna przynależność), religijność ukryta (latentna, bezobjawowa), religijność „rozmyta”, sfragmentaryzowana, zderegulowana, powierzchowna chrześcijańska tożsamość kulturowa.

Teza postsekularyzacyjna wydaje się zyskiwać coraz więcej zwolenników, chociaż najprawdopodobniej mamy tu do czynienia bardziej ze sporem semantycznym niż merytorycznym. Także zahamowanie procesów sekularyzacyjnych nie może być interpretowane jako likwidacja czwartego filaru nowoczesności. Postsekularyzacja i desekularyzacja są rozumiane zarówno jako zmiany według osi wertykalnej,

${ }^{58}$ P.L. Berger, Dialog zwischen religiösen Traditionen in einem Zeitalter der Relativität, Mohr Siebeck, Tübingen 2011, ss. 11-15; P.L. Berger, Etyka społeczna w świecie postsocjalistycznym, tłum. J.J. Franczak, A. Kowal, „First Things. Edycja Polska” 2008, nr 6, ss. 26-33.

${ }^{59}$ P.L. Berger, Religion und europäische Integration. Bemerkungen aus Amerika, w: Woran glaubt Europa? Religion und politische Kultur im neuen Europa, Hrsg. von Krzysztof Michalski, Passagen Verlag, Wien 2007, s. 231. 
jak i horyzontalnej. Desekularyzacja nie oznacza odwrócenia kierunku procesu modernizacji społeczeństw, co pociągnęłoby za sobą przywrócenie im charakteru społeczeństw przednowoczesnych czy przedindustrialnych, a jest to - jak podkreśla Peter L. Berger - „cel tak niemożliwy do osiągnięcia, jak nic innego w historii” ${ }^{\text {. }}$. Oznacza ona tylko inną relację do nowoczesności i modernizacji społecznej.

W społeczeństwach silnie zsekularyzowanych odradzają się ruchy fundamentalistyczne. Wspólną cechą ruchów fundamentalistycznych jest wielkie religijne uniesienie, odrzucenie tego, co jest nazywane „duchem czasu” (Zeitgeist) i powrót do tradycyjnych źródeł religijnego autorytetu. Wspólne jest także przeciwstawianie się nurtom sekularyzacyjnym. Według Bergera nowoczesność podważa wszelkie pewniki, a wytworzona niepewność jest nie do zniesienia dla części ludzi współczesnych. W tej sytuacji każdy ruch (nie tylko religijny), który obiecuje dostarczenie albo odnowienie poczucia pewności, ma zapewniony rynek zbytu swoich „towarów”1 . Ci, którzy czują się niepewnie w społecznej i kulturowej różnorodności, poszukują w ruchach fundamentalistycznych koniecznych zabezpieczeń. W dziedzinie religijnej fundamentalizm wyraża się między innymi w powrocie do integralności w odniesieniu do doktryny i liturgii, w żądaniach wzmocnienia wiary i charyzmatycznej odnowy, w oczekiwaniach wzrostu zaufania do Kościoła, w akceptacji tradycyjnych wartości. Ruchy fundamentalistyczne w Kościele przyczyniają się - wprost lub pośrednio - do jego integracji w pewnych środowiskach, z drugiej strony grożą rozłamem lub są przejawem dezintegracji wewnątrzkościelnej.

Faktycznie funkcjonująca religijność jest wewnętrznie zróżnicowana i spluralizowana, aż po formy niejasnej, niezinstytucjonowanej, sfragmentaryzowanej religijności, często o charakterze synkretycznym. Można by ją nazwać religijnością „niewidzialną”, bowiem sytuuje się raczej w prywatnej sferze życia, tylko ubocznie ujawnia się w zobiektyzowanych symbolach i zbiorowych rytuałach, nie tylko poza chrześcijaństwem, ale i w jego obrębie. Nowe ruchy religijne, zwane religiami młodzieżowymi, ruchami alternatywnymi, psychogrupami, okultyzmem, ezoteryzmem itp., a także ruchy fundamentalistyczne, charyzmatyczne i inne, są niezwykle zróżnicowane. Trudno byłoby sprowdzić ich cechy do wspólnego mianownika.

Peter L. Berger wskazuje na rozkwit życia duchowego we współczesnym świecie.

Ludzie mówią: „Nie jestem człowiekiem religijnym, ale mam swoją duchowośc”. Takie deklaracje mogą mieć rozmaity sens. Bywają świadectwem wierzeń spod znaku New Age - wiary w jedność rzeczywistości osobowej i kosmicznej, w możliwość osiągnięcia owej jedności poprzez praktyki medytacyjne bądź w znalezienie własnego, autentycznego ,ja” poprzez odkrycie „dziecka w sobie”. Często jednak sens jest prostszy:

${ }^{60}$ P.L. Berger. Święty baldachim..., s. 178.

${ }^{61}$ P.L. Berger, The Desecularization of the World..., ss. 6-7; P.L. Berger, Secularization and de-secularization, ss. 291-329. 
„Jestem człowiekiem religijnym, ale nie potrafię się utożsamić z żadnym konkretnym Kościołem czy tradycją religijną"62.

Europejczycy budują swoją indywidualną religijność w sposób niezorganizowany, nie tworzą nowych instytucji religijnych, które odzwierciedlałyby ich zainteresowania religijne. W kulturze amerykańskiej - przeciwnie - istnieje mocno zakorzeniona tradycja zakładania stowarzyszeń, znacznie częściej ludzie angażują się w nowe wspólnoty wyznaniowe.

Tam, gdzie religijny rynek nie jest redukowany do ofert Kościołów, lecz rozwija się w kierunku pluralizmu ofert, tam wzrasta witalność religijna. Istnieje ścisły związek pomiędzy podażą i popytem na rynku religijnym. Ludzie zawsze będą poszukiwać odpowiedzi na ostateczne problemy swojej egzystencji i będą ich poszukiwać na pluralistycznym rynku religijnym. Zgodnie z teorią racjonalnego wyboru kierują się oni w swoich decyzjach i działaniach zasadą maksymalizacji zysków. Także w obszarze religii dokonuje się swoisty przetarg zysków i strat, rachunek „nadnaturalny”. To właśnie wolny rynek religii wyjaśnia - przynajmniej do pewnego stopnia - wysoką religijność ludności w USA, podczas gdy monopolistyczne tendencje kościelne w Europie przyczyniły się do kryzysu religijności ${ }^{63}$.

Peter L. Berger wyraża pogląd, że nowoczesność nie przyniosła ze sobą upadku religii, lecz doprowadziła do jej przekształceń. Teoria sekularyzacji opierała się na założeniu, że modernizacja społeczna prowadzi nieuchronnie do zaniku religii. Socjologowie poddawali nadinterpretacji pewne fakty świadczące o sekularyzacji, także pluralizm społeczny i religijny interpretowano jako przejaw sekularyzacji. Teoria sekularyzacyjna przyjmowała - mniej lub bardziej wyraźnie - tezę, że modernizacja społeczna prowadzi nieuchronnie do zaniku religii. Na podstawie wyników badań socjologicznych - twierdzi Peter L. Berger - ta teoria już dzisiaj w swojej klasycznej formie jest nie do utrzymania. Potrzebujemy dzisiaj innego paradygmatu, a jest nim teoria pluralizmu, opierająca się na koegzystencji różnych religii i koegzystencji sekularnego oraz religijnego dyskursu ${ }^{64}$.

Świat współczesny charakteryzuje nie tyle sekularyzacja, ile raczej ważniejszy od niej fenomen pluralizacji religijnej.

Podstawowe procesy modernizacji - takie jak powszechne szkolnictwo, urbanizacja, rozwój środków masowego przekazu - prowadzą do współwystępowania obok siebie na pokojowych warunkach różnych punktów widzenia i systemów wartości. To niezwykle ważne zjawisko, które zmienia naturę religii, ale niekoniecznie jest tożsame z jej zanikiem. Pluralizm i rozmnożenie dostępnych możliwości oraz związana z tym konieczność wyboru nie muszą prowadzić do wyboru laicyzmu. Równie dobrze człowiek nowoczesny może wybrać religię, choć warunki, w jakich tego dokonuje,

${ }^{62}$ P.L. Berger, Zachód z Bibliq w tle, s. 18.

${ }_{63}$ P.L. Berger, Nach dem Niedergang der Säkularisierungstheorie, ss. 1-9.

${ }^{64}$ P.L. Berger, Altäre der Moderne. Religion in pluralistischen Gesellschaften, Campus Verlag, Frankfurt am Main 2015, s. 7. 
zmieniają zarówno strukturę instytucjonalną poszczególnych kościołów, jak również indywidualne doświadczenie religijne. [...]. Żadna tradycja religijna czy kulturowa nie jest już uznawana za niepodważalny pewnik. Zamiast tego nieustannie podlega kwestionowaniu, czyli innymi słowy zostaje zrelatywizowana. To bardzo powszechne zjawisko, nie tylko w Europie ${ }^{65}$.

Nowoczesność prowadzi do pluralizmu, który podważa oczywistość religijną, ale otwiera również mnóstwo poznawczych i normatywnych możliwości wyboru. Pluralizm jest dla wiary ważnym wyzwaniem, ale nie musi on prowadzić do sekularyzacji. Pluralizm religijny rozwija się na płaszczyźnie indywidualnej i zbiorowej (kolektywnej), ma swoje różnorodne oblicza.

W warunkach pluralizmu społeczno-kulturowego tożsamość religijna nie jest we współczesnym świecie tym, co jest dane, lecz tym, co jest zadane. Jednostki samodzielnie konstruują własne tożsamości, swoje światopoglądy, swój system wartości moralnych. Pluralizm społeczny oraz jego społeczna i psychologiczna dynamika sprawiają, że jednostkom coraz trudniej jest utrzymać pewność światopoglądową, nie angażując się w nieustanny proces walki z samym sobą i światem zewnętrznym. Religijność przestaje być częścią kulturowego dziedzictwa, wybór religii staje się świadomą decyzją jednostki ${ }^{66}$. W warunkach ponowoczesności tożsamości religijne są mocno zróżnicowane.

\section{Uwagi końcowe}

Zarówno modernizacja, jak i sekularyzacja przyjmują różne formy i będą w przyszłości rozwijać się w różnych kierunkach, w zależności od całego kontekstu społeczno-kulturowego i zróżnicowanych tradycji narodowych. Wiele jest odmian modernizacji, a zachodnioeuropejska modernizacja nie jest jedyną modernizacją. Nie każda modernizacja musi ex definitione prowadzić do utraty znaczenia religii i pozycji społecznej Kościołów. Nie wszystkie odmiany modernizacji społecznej łączą się z sekularyzacją. Paradoksalnie, postępująca sekularyzacja - do pewnego stopnia - wpływa na poszerzenie się tak zwanego pola duchowego (,niereligijni, ale duchowi”). Teoria sekularyzacji, która powstała na gruncie europejskim, nie jest już wystarczającym wytłumaczeniem przemian w religijności współczesnej, potrzebne są nowe paradygmaty w socjologii religii. Coraz częściej socjologowie podkreślają, że nowoczesność czy modernizacja społeczna nie muszą wiązać się nieodłącznie z sekularyzacją. Powrót Boga jest możliwy, a nawet realny. Marksistowski ateizm nie ma większych szans poza murami uniwersytetów ${ }^{67}$.

${ }^{65}$ Religia i nowoczesność. Rozmowa z amerykańskim socjologiem religii Peterem L. Bergerem, s. 24.

${ }^{66}$ Ibidem.

${ }^{67}$ P.L. Berger, Adventures of an accidental Sociologist..., s. 138. 
Jeżeli nawet modernizacja nie zawsze pociąga za sobą sekularyzację, to - jak twierdzi Peter L. Berger - podważa przekonania i wartości uważane dawniej za oczywiste (wielki inkubator relatywizmu), co dotyczy również religii. O ile w społeczeństwach tradycyjnych panował wysoki poziom zgodności w kwestiach podstawowych założeń poznawczych i normatywnych, a wartości i normy religijne oraz moralne mogły wydawać się oczywiste i niekwestionowane, to w czasach współczesnych podlegają one procesowi daleko idącej pluralizacji (odchodzenie od obowiązującej ortodoksji). Pluralizm przybiera gwałtowne formy („huraganowy” pluralizm), w pewnym sensie globalizuje się, dotyczy zarówno płaszczyzny instytucjonalnej, jak i świadomości jednostek. Kształtuje się swoisty rynek światopoglądów i systemów normatywnych, swoisty rynek preferencji religijnych, co oznacza w praktyce odejście od kondycji losu do kondycji wyboru w sprawach religijnych $^{68}$. Socjolog francuski Yves Lambert stawia nawet tezę, że im bardziej jest zsekularyzowane społeczeństwo, w tym większym stopniu są widoczne procesy desekularyzacji w sensie rozwijania się autonomicznej religijności ${ }^{69}$.

Socjologowie współcześni z większą powściągliwością mówią o bezkościelnym czy bezreligijnym społeczeństwie (społeczeństwo bez Boga), a nawet uznają do pewnego stopnia religię za trwały element ludzkiego życia. Wielu z nich nie podziela poglądu, że nowoczesność ze swej istoty jest wroga religii. Nie postulują tworzenia społeczeństwa bez Boga. Sekularyzacja wywołuje skutki destrukcyjne, ale i pobudza rozwój religijności określonego typu ${ }^{70}$. Faktem są upowszechniające się procesy pluralizacji społeczno-kulturowej, które sprawiają, że ludzie żyją dzisiaj w całkowicie nowej sytuacji, nacechowanej wielością konkurencyjnych przekonań i stylów życia. Nie pozostaje to bez wpływu na religijność ludzi współczesnych ${ }^{71}$.

Część socjologów europejskich i amerykańskich mówi coraz częściej o procesach desekularyzacji, o ponownym „zaczarowaniu świata”, a nawet o końcu sekularyzacji. Wskazują oni na nowe formy religijności i duchowości, na możliwą koegzystencję religii i nowoczesności, a nawet na kontrsekularyzację, rewitalizację religii, na procesy respirytualizacji i na megatrendy religijne. Te nowe formy religii i duchowości pełnią swoistą funkcję barometrów zmian społecznych o bardziej ogólnym charakterze. Sacrum nie znika, lecz zmienienia swoje miejsce w społeczeństwie. Ujawnia się ono w nowych postaciach poza Kościołem. Dzisiaj część socjologów mówi nawet z przesadą o końcu sekularyzacji, niektórzy chcą wykreślać sekularyzację ze słownika socjologicznego, a tezę sekularyzacyjną jako fałszywą

${ }^{68}$ P.L. Berger, Refleksje o dzisiejszej socjologii religii, s. 95; P.L. Berger, Der Zwang zur Häresie. Religion in der pluralistischen Gesellschaft, S. Fischer Verlag, Frankfurt am Main 1980, ss. 14-15.

${ }^{69}$ Y. Lambert, A Turning Point in Religious Evolution in Europe, ,Journal of Contemporary Religion” 2004, vol. 19, nr 1, ss. 29-45.

${ }^{70}$ R. Stark, W.S. Bainbridge, Teoria religii, tłum. T. Kunz, Zakład Wydawniczy Nomos, Kraków 2000, ss. 366 i 391.

${ }^{71}$ P.L. Berger Nach dem Niedergang der Säkularisierungstheorie, s. 2. 
proponują odprowadzić na cmentarz z modlitwami requiescat in pace (pożegnanie z teorią sekularyzacji jako bezużyteczną, a nawet nienaukową).

Warto przywołać w tym miejscu ważną refleksję Petera L. Bergera:

Trendy społeczne nie działają na zasadzie nieuchronnej, niezależnej od idei i działań ludzi. Nowoczesność jako taka nie jest żadną siłą natury, lecz rezultatem praktyki ludzi myślących i działających w określony sposób. Nie ma więc takiej przedustawnej konieczności, zgodnie z którą nowoczesne społeczeństwa muszą być z istoty świeckie. Czy się takie staną, zależy od naszych działań: od świadomych wyborów jednostek, niezamierzonych następstw tych wyborów, a także walk o władzę i wpływy między rozmaitymi grupami. Czy to w Ameryce, Europie, czy na Bliskim Wschodzie wciąż jeszcze jest miejsce na dokonywanie wyborów co do miejsca religii w społeczeństwie i państwie. Dlatego też ważne jest, by dobrze i jasno zrozumieć wszystkie alternatywne $\operatorname{drogi}^{72}$.

Powoli tracą na znaczeniu męczące dyskusje o zanikającej czy niezanikającej roli religii w społeczeństwie i w świecie, na rzecz bardziej istotnych dyskusji o miejscu i roli religii w społeczeństwach współczesnych. Erozja religijności i osłabienie społecznego znaczenia Kościołów chrześcijańskich w Europie, zwłaszcza Zachodniej, to przypadek szczególny, który wymaga głębokich wyjaśnień socjologicznych. Wydaje się, że sam Berger nieco przeakcentował znaczenie pluralizmu dla dynamiki religijnej i nie doceniał ruchów sekularystycznych i sekularnych we współczesnym świecie, a także potencjału konfliktu między religijną i sekularną wizją świata. Pluralizm w swoich różnych postaciach (konfesyjny, religii, religijności) jest ważną „sygnaturą” czasów współczesnych, ale nie oznacza on końca procesów sekularyzacyjnych. Co więcej, wiele wskazuje na to, że konflikt między religiami i ideologiami sekularnymi będzie się nasilał w przyszłości. Nie będzie to oznaczać końca religijności, ale - być może - jej nowe konfiguracje i metamorfozy ${ }^{73}$.

Zakończmy te rozważania syntetyczną refleksją Petera L. Bergera:

Jako chrześcijanin powiedziałbym, że ludzie garną się do religii, ponieważ religia jest prawdziwa, a każda prawda ma moc przebicia do ludzkiej świadomości. Tego jednak nie mogę powiedzieć jako socjolog. Powiem więc jedynie, że ludzie wykazują potrzebę nadania własnej egzystencji jakiegoś ostatecznego sensu - zwłaszcza w obliczu zła, cierpienia czy śmierci. Potrzeba ta zdaje się być niezbywalna - mimo licznych prób jej usuwania nieustannie pojawia się w tej lub innej formie. Wychodząc z takiego założenia,

72 P.L. Berger, Alternatywne nowoczesności, www.newsweek.pl/alternatywne-nowoczesnosci,45397,1,1.html; P.L. Berger, Th. Luckmann, Modernität, Pluralismus und Sinnkrise. Die Orientierung des modernen Menschen, Verlag Bertelsmann Stiftung, Gütersloh 1995; P.L. Berger, Th. Luckmann, Socjologia religii a socjologia wiedzy, w: Socjologia religii. Wybór tekstów, red. W. Piwowarski, Zakład Wydawniczy Nomos, Kraków 1998, ss. 131-138.

${ }^{73}$ S. Steets, „And then I put on a different hat...”. Über das Verhältnis von Soziologie und Theologie im Werk Peter L. Bergers, w: Im Gespräch mit Peter L. Berger. Eine Gedenkschrift zu den Perspektiven und Grenzen religiöser Pluralität, Hrsg. von Wolfram Weiße, Silke Steets, Waxmann Verlag, Münster 2019, ss. 15-31. 
nie jesteśmy w stanie przewidzieć konkretnego kształtu, w jakim religia będzie powracać do naszego życia, ale w jakiejś formie na pewno powróci. Całkowicie areligijne, świeckie światopoglądy mają jedną zasadniczą wadę - nie pomagają ludziom w radzeniu sobie ze zwyczajnymi życiowymi kryzysami. Weźmy na przykład oddanego swojej sprawie marksistę. Jeśli polegnie on w walce o zwycięstwo rewolucji, wówczas jego śmierć ma sens. Jeśli jednak umrze w łóżku na raka płuc, ideologia nie odpowie mu na pytanie o celowość tej śmierci. Potrzeba wyjaśnienia sensu cierpienia, zła i skończoności to czynnik, który napędza żywotność różnego rodzaju kultów religijnych ${ }^{74}$.

\section{Literatura}

Adamczyk T., Desekularyzacja w warunkach globalizacji, w: Religia i religijność w warunkach globalizacji, red. M. Libiszowska-Żółtkowska, Zakład Wydawniczy Nomos, Kraków 2007.

Berger P.L., Adventures of an accidental Sociologist. How to explain the world without becoming a bove, Prometheus Books, New York 2011.

Berger P.L., Altäre der Moderne. Religion in pluralistischen Gesellschaften, Campus Verlag, Frankfurt am Main 2015.

Berger P.L., Alternatywne nowoczesności, www.newsweek.pl/alternatywne-nowoczesnosci,45397,1,1.html [dostęp: 3.05.2019].

Berger P.L., Alternatywne nowoczesności. Euroświeckość i amerykańska religia, tłum. A. Bielik-Robson, „Fakt” 2005, nr 220 (dodatek „Europa”, nr 38).

Berger P.L., Auf der Suche nach einer Friedensformel: Replik, w: Nach dem Niedergang der Säkularisierungstheorie, Centrum für Religion und Moderne - Westfälische Wilhelms-Universität Münster, Münster 2013.

Berger P.L., Brigitte Berger. Individuum \& Co. Soziologie beginnt beim Nachbarn, Deutsche Verlag-Anstalt, Stuttgart 1974.

Berger P.L., Der Zwang zur Häresie. Religion in der pluralistischen Gesellschaft, S. Fischer Verlag, Frankfurt am Main 1980.

Berger P.L., Dialog zwischen religiösen Traditionen in einem Zeitalter der Relativität, Mohr Siebeck, Tübingen 2011.

Berger P.L., Etyka społeczna w świecie postsocjalistycznym, tłum. J.J. Franczak, A. Kowal, „First Things. Edycja Polska” 2008, nr 6.

Berger P.L., Further Thoughts on Religion and Modernity, „Society” 2012, 49.

Berger P.L., Między relatywizmem i fundamentalizmem, tłum. R. Lewandowski, „W drodze” 2007, nr 9.

Berger P.L., Modernizacja jako uniwersalizacja herezji, tłum. B. Mikołajewska, w: Religia a życie codzienne, t. 1, red. H. Grzymała-Moszczyńska, Instytut Religioznawstwa Uniwersytetu Jagiellońskiego, Kraków 1990.

${ }^{74}$ Religia i nowoczesność. Rozmowa z amerykańskim socjologiem religii Peterem Bergerem; M. Rembierz, Edukacja międzykulturowa jako ćwiczenie duchowe. Pedagogiczne wymiary kształtowania kultury duchowej i rozumienia wartości ponadkulturowych w kontekście zróżnicowania religijnego i pluralizmu światopoglq̨dowego, „Edukacja Międzykulturowa” 2018, nr 2, ss. 90-130. 
Berger P.L., Nach dem Niedergang der Säkularisierungstheorie, Centrum für Religion und Moderne - Westfälische Wilhelms-Universität Münster, Münster 2013.

Berger P.L., Pytania o wiarę. Sceptyczna zachęta do chrześcijaństwa, tłum. J. Łoziński, Instytut Wydawniczy Pax, Warszawa 2007.

Berger P.L., Refleksje o dzisiejszej socjologii religii, tłum. K. Marulewska, „Teologia Polityczna” 2009/2010, nr 1 s. 90.

Berger P.L., Religion und europäische Integration. Bemerkungen aus amerikanischer Sicht, „Transit. Europäische Review” 2004, nr 27.

Berger P.L., Religion und europäische Integration. Bemerkungen aus Amerika, w: Woran glaubt Europa? Religion und politische Kultur im neuen Europa, Hrsg. von Krzysztof Michalski, Passagen Verlag, Wien 2007.

Berger P.L., Secularization and de-secularization, w: Religious in the Modern World. Traditions and transformations, ed. L. Woodhead, P. Fletcher, H. Kawanami, D. Smith, London 2002.

Berger P.L., Sehnsucht nach Sinn. Glauben in einer Zeit der Leichtgläubigkiet, Kamphausen J. Verlag, Frankfurt am Main 1994.

Berger P.L., Sekularyzacja a problem wiarygodności religii, tłum. W. Kurdziel, w: Ateizm i irreligia oraz sekularyzacja, red. F. Adamski, Petrus, Kraków 2011.

Berger P.L., Sekularyzacja a problem wiarygodności religii, w: Socjologia religii, red. F. Adamski, Wydawnictwo Apostolstwa Modlitwy, Kraków 1983.

Berger P.L., Święty baldachim. Elementy społecznej teorii religii, tłum. W. Kurdziel, Zakład Wydawniczy Nomos, Kraków 1971.

Berger P.L., The Desecularization of the World: A Global Overview, w: The Desecularization of the World: Resurgent Religion and World Politics, ed. P.L. Berger, Ethics and Policy Center, Washington 1999.

Berger P.L., Trzeci świat jako idea religijna (fragmenty), „Pismo Literacko-Artystyczne” 1986, vol. 5, nr 6-7.

Berger P.L., Weiße W., Im Gespräch: Religiöse Pluralität und gesellschaftlicher Zusammenhalt, w: Religiöse Differenz als Chance? Positionen, Kontroversen, Perspektiven, Hrsg. von Wolfram Weiße, Hans-Martin Gutmann, Waxmann, Münster 2010.

Berger P.L., Zachód z Bibliq w tle, „Gazeta Wyborcza” z 2005 r., nr 158.

Berger P.L., Zasada wątpliwości. Poza relatywizmem i fundamentalizmem, tłum. T. Bieroń, „Dziennik” 2008, nr 93 (dodatek „Europa”, nr 16).

Berger P.L., Zijderveld A.C., Pochwała wątpliwości. Jak mieć przekonania i nie stać się fanatykiem, tłum. S. Baranowski, vis-á-vis Etiuda, Kraków 2010.

Berger P.L., Zur Dialektik von Religion und Gesellschaft, Fischer Verlag, Frankfurt am Main 1967.

Berger P.L., Berger B., Kellner H., Bezdomny umysł, w: Zjawisko wspólnoty (Wybór tekstów), red. B. Mikołajewska, Instytut Profilaktyki i Resocjalizacji Społecznej UW, Warszawa 1989.

Berger P.L., Berger B., Kellner H., Das Unbehagen in der Modernität, Campus Verlag, Frankfurt am Main-New York 1975.

Berger P.L., Luckmann Th., Modernität, Pluralismus und Sinnkrise. Die Orientierung des modernen Menschen, Verlag Bertelsmann Stiftung, Gütersloh 1995.

Berger P.L., Luckmann Th., Socjologia religii a socjologia wiedzy, w: Socjologia religii. Wybór tekstów, red. W. Piwowarski, Zakład Wydawniczy Nomos, Kraków 1998. 
Boguszewski R., Religijność i moralność w społeczeństwie polskim: zależność czy autonomia? Studium socjologiczne, Wydawnictwo Adam Marszałek, Toruń 2012.

Borowik I., Berger Peter Ludwig, w: Leksykon socjologii religii. Zjawiska - badania - teorie, red. M. Libiszowska-Żółtkowska, J. Mariański, Verbinum Wydawnictwo Księży Werbistów, Warszawa 2004.

Borowik I., Socjologia religii Petera L. Bergera, w: Święty baldachim. Elementy społecznej teorii religii, tłum. W. Kurdziel, Zakład Wydawniczy Nomos, Kraków 1971.

Davie G., Socjologia religii, tłum. R. Babińska. Zakład Wydawniczy Nomos, Kraków 2010.

Doktór T., Wokół problemu sekularyzacji, w: P. Norris, R. Inglehart, Sacrum i profanum. Religia i polityka na świecie, tłum. R. Babińska, Zakład Wydawniczy Nomos, Kraków 2006.

Drozdowicz Z., Between the temptations of privatizing and globalizing religion, „Przegląd Religioznawczy” 2014, nr 1.

Drozdowicz Z., Wiara i niewiara w Boga amerykańskich uczonych, „Przegląd Religioznawczy” 2019, nr 2.

Epistemological Modesty: an Interview with Peter Berger, „Christian Century” 1997, vol. 114, nr 30.

Eßbach W., Religionssoziologie. Entfesselter Markt und Artifizielle, Lebenswelt als Wiege neuer Religionen, Bd. 2, Wilhelm Fink Verlag, Paderborn 2019.

Filozof o czasach sekularyzacji. Charles Taylor w rozmowie z Mateuszem Burzykiem i Mirosławem Jędrzejkiem, „Znak” 2019, nr 12.

Kaufmann F.-X., Wie überlebt das Christentum?, Verlag Herder, Freiburg im Breisgau 2000.

Knauth T., Peter Bergers Religionstheorien, ihre Bedeutung für die Entwicklung einer pluralitätsfähigen Religionspädagogik, w: Im Gespräch mit Peter L. Berger. Eine Gedenkschrift zu den Perspektiven und Grenzen religiöser Pluralität, Hrsg. von Wolfram Weiße, Silke Steets, Waxmann Verlag, Münster 2019.

Knight Ch.J., Charlesa Taylora A Secular Age: impuls apofatyczny, tłum. J. Adamko, w: Charlesa Taylora wizja nowoczesności. Rekonstrukcje i interpretacje, red. Ch. Garbowski, J.P. Hudzik, J. Kłos, Oficyna Wydawnicza Łośgraf, Warszawa 2012.

Knoblauch H., Silke Steets. Dialektik und Dialog im Dazwischen. Nekrolog auf Peter L. Berger (1929-2017) und Thomas Luckmann (1927-2016), „Berliner Journal für Soziologie” 2018, vol. 27, nr 3-4, ss. 595-601.

Kutyło Ł., Między sekularyzacją a desekularyzacją. W poszukiwaniu globalnej teorii przemian religijnych, „Annales Universitatis Paedagogicae Cracoviensis. Studia Sociologica” VI, 2014, nr 1.

Lambert Y., A Turning Point in Religious Evolution in Europe, ,Journal of Contemporary Religion” 2004, vol. 19, nr 1.

Majka J., Metodologia nauk teologicznych, Wydawnictwo Wrocławskiej Księgarni Archidiecezjalnej, Wrocław 1981.

Mariański J., „Odkościelnienie” i indywidualizacja jako ważne tendencje przemian religijności współczesnej, „Zeszyty Naukowe. Publikacje z zakresu europejskiej integracji, polityki i bezpieczeństwa. Redakcja Zeszytów Naukowych Akademii Marynarki Wojennej”, Gdynia 2010.

Mariański J., Europa bez Boga? Między sekularyzacjq i desekularyzacjq w społeczeństwie postsekularnym, w: Janusz Mariański. Doctor Honoris Causa Universitatis Silesiensis, Wydawnictwo Uniwersytetu Śląskiego, Katowice 2019. 
Mariański J., Nowa religijność i duchowość - mit czy rzeczywistość? Studium socjologiczne, Warszawskie Wydawnictwo Socjologiczne, Warszawa 2019.

Mariański J., Religia i religijność w społeczeństwie tradycyjnym i nowoczesnym w ujęciu Petera L. Bergera, „Collectanea Theologica” 2020, vol. 90, nr 2.

Mariański J., Sekularyzacja we współczesnym świecie w ujęciu Petera L. Bergera, w: Społeczeństwo - kultura - wychowanie. Księga jubileuszowa dedykowana Profesorowi Januszowi Sztumskiemu z okazji 90-lecia urodzin, red. F. Bylok, M. Łapot, K. Rędziński, Uniwersytet Humanistyczno-Przyrodniczy im. Jana Długosza w Częstochowie, Częstochowa 2020.

Mariański J., Sekularyzacja, w: Leksykon socjologii religii. Zjawiska - badania - teorie, red. M. Libiszowska-Żółtkowska, J. Mariański, Verbinum Wydawnictwo Księży Werbistów, Warszawa 2004.

Milerski B., Religia w społeczeństwie pluralistycznym, w: Elementy pedagogiki religijnej, red. B. Milerski, Chrześcijańska Akademia Teologiczna, Warszawa 1998.

Persönliches und Gesellschaftliches. Ein Gespräch mit Peter L. Berger, Emil Brix und Manfred Prisching, w: Gesellschaft verstehen. Peter L. Berger und die Soziologie der Gegenwart, Hrsg. von M. Prisching, Passagen Verlag, Wien 2001.

Pollack D., Religion und Moderne: Theoretische Überlegungen und empirische Beobachtungen, w: Moderne und Religion. Kontroversen um Modernität und Säkularisierung, Hrsg. von Ulrich Willems, Detlef Pollack, Helene Basu, Thomas Gutmann, Ulrike Spohn, Transcript Verlag, Bielefeld 2013.

Religia i nowoczesność. Rozmowa z amerykańskim socjologiem religii Peterem Bergerem, „Europa. Miesięcznik Idei” 2012, nr 5.

Rembierz M., Edukacja międzykulturowa jako ćwiczenie duchowe. Pedagogiczne wymiary kształtowania kultury duchowej i rozumienia wartości ponadkulturowych w kontekście zróżnicowania religijnego i pluralizmu światopoglq̨dowego, „Edukacja Międzykulturowa” 2018, nr 2.

Schmidt-Lux T., Peter L. Berger: religia jako święty kosmos, w: Filozofia religii (od Schleiermachera do Eco), red. V. Drehsen, W. Gräb, B. Weyel, tłum. L. Łysień, Wydawnictwo WAM, Kraków 2008.

Sroczyńska M., Życie „na przemiał“ a religia - wyzwanie dla socjologa, w: Religia a gospodarka. Suplement, red. S. Partycki, Wydawnictwo KUL, Lublin 2005.

Stark R., Bainbridge W.S., Teoria religii, tłum. T. Kunz, Zakład Wydawniczy Nomos, Kraków 2000.

Steets S., „And then I put on a different hat...”. Über das Verhältnis von Soziologie und Theologie im Werk Peter L. Bergers, w: Im Gespräch mit Peter L. Berger. Eine Gedenkschrift zu den Perspektiven und Grenzen religiöser Pluralität, Hrsg. von Wolfram Weiße, Silke Steets, Waxmann Verlag, Münster 2019.

Weiße W., Die moralischen Grenzen religiöser Pluralität. Grundidee und Strategie eines unvollendeten Großprojektes von Peter L. Berger, w: Religiöse Differenz als Chance? Positionen..., Hrsg. von Wolfram Weiße, Hans-Martin Gutmann.

Wójtowicz A., Doctrina sacra, ezoteryzm - oswajanie tajemnicy, w: Pluralizm religijny i odmiany ezoteryzmu, red. A. Wójtowicz, W. Klimski, Wydawnictwo Naukowe Uniwersytetu Kardynała Stefana Wyszyńskiego w Warszawie, Warszawa 2019.

Zulehner P.M., Ein neues Pfingsten. Ermutigung zu einem Weg der Hoffnung, Schwabenverlag, Ostfildern 2008. 
